INVITED PAPER

\author{
James C. Klagge
}

jklagge@vt.edu

\title{
The Wittgenstein Lectures, Revisited
}

\section{Abstract}

This essay surveys what is known about Wittgenstein's philosophical lectures, covering the Cambridge Moral Sciences Club, Cambridge University courses, and other lecture venues. Information provided includes titles, dates, locations, attendees and content, to the extent these are known. Sometimes content is simply referred to by citations of other publications. When it is relatively brief or difficult to access, content is occasionally provided directly. The original survey, published in 2003, is here updated, corrected and expanded.

\section{Preface}

In 2003 I published a survey of Wittgenstein's lectures in Public and Private Occasions. Much has been learned about his lectures since then. This paper revisits the earlier survey and provides additional material and corrections, which amount to over $25 \%$. In case it is useful, I have provided interlinear pagination from the original publication. If additional material or corrections come to light, I will update the paper as needed on my website: jamesklagge.net 


\section{THE LECTURES}

[[p. 331]] Just as we have a catalogue of Wittgenstein's papers, it would be useful to have a guide to Wittgenstein's lectures. It would be useful to know when he gave lectures, where and to whom, and on what topics, and more specifically what he said.

Since his lectures, unlike his papers, have no enduring existence, they are harder to study. Nevertheless, we have evidence about his lectures-comments he made in letters, notes he made in preparation, recollections and notes from his listeners and friends, official records and minutes, diary entries, and so forth.

Though Wittgenstein nearly always lectured extemporaneously, the lectures were preceded by enormous preparation, and Wittgenstein took them very seriously. As Norman Malcolm has reported (1984: 48), Wittgenstein "said that he had always regarded his lectures as a form of publication." And Casimir Lewy recalled: "Wittgenstein once said to me that 'to publish' means 'to make public', and that therefore lecturing is a form of publication" (1976: xi).

Yorick Smythies, who probably attended more of Wittgenstein's lectures than any other student, wrote the following in a draft of an introduction to a planned publication of Wittgenstein's lectures (Smythies 2017, xi):

Re-reading [these notes], now, after thirty years, I find them more natural, fluent, simple, continuous, expressive, than the remarks contained in Wittgenstein's so-far published writings [...]. While he was lecturing, he was not able to delete what had been said, or to give to trains of thought more tightness than they were showing themselves to have. Also, tones which give personal expressiveness to his lectures became omitted, automatically, from his writings. The expletives, interjectory phrases, slangy asides, etc., which were essentially constituent in what he was saying to his classes, would have shown affectation if they had been addressed to the general, reading, public.

Wasfi Hijab, a student of Wittgenstein's during his last two years at Cambridge, claimed (1999) that teaching was the only way Wittgenstein could adequately convey his thought. [[332]]

While it is futile to argue over the relative merits of his lectures and his manuscripts as avenues to understanding Wittgenstein's 
philosophy, it is clear that his lectures played a central part in his philosophical life. They gave him countless opportunities, or forced upon him countless occasions, to articulate his ideas. Unlike his manuscripts, wherein the interlocutor was invariably himself, his lectures kept him in contact with other people. These people have had an enormous influence on the philosophical reception of Wittgenstein's ideas. His lectures also provoked him to address a wider range of issues than he tended to write about. That he finally retired from teaching because it hindered his attempt to bring his manuscript to completion (Malcolm 1984: 103: letter to Malcolm, August 27, 1947; Drury 1984: 153; and Bouwsma 1986: 9) in no way detracts from the central role his teaching played in stimulating and propagating his work.

I have divided Wittgenstein's lectures into three categories: (1) talks to the Cambridge Moral Sciences Club, (2) Cambridge University course lectures, and (3) lectures given on other occasions. In the first and third groups I have sometimes included Wittgenstein's participation in public discussions, even when he was not the "lecturer".

\section{Talks to the Cambridge Moral Sciences Club}

The Cambridge Moral Sciences Club (CMSC) gave students and faculty an opportunity to hear and discuss papers of philosophical interest from Cambridge students and faculty, as well as from faculty outside of Cambridge. Meetings generally lasted one and a half to three hours. (See Pitt 1981-1982 for the history and nature of the club.)

Wittgenstein arrived in Cambridge in October 1911 and was first listed as a member of the CMSC for the year 1912-1913. Wittgenstein recommended in 1912 that no paper should last longer than seven minutes (Moore's letter to Hayek, in Nedo and Ranchetti 1983: 79). The club adopted the recommendation on November 15, 1912. 


\section{November 29, 1912, "What Is Philosophy?"}

Minutes for the meeting, held in Wittgenstein's rooms, with G. E. Moore in the chair, record that about fifteen members were present:

Mr Wittgenstein [...] read a paper entitled 'What is Philosophy?' The paper lasted only about 4 minutes, thus cutting the previous record established by Mr Tye by nearly two minutes. Philosophy was defined as all those primitive propositions which are assumed as true without proof by the various sciences. This defn. was much discussed, but there was no general disposition to adopt it. The discussion kept very well to the point, and the Chairman did not find it necessary to intervene much.

(The minutes, which are available for consultation at the Cambridge University library, are presented in facsimile in Nedo and Ranchetti 1983: 89.) [[333]]

Wittgenstein left Cambridge in 1913 and did not return to its academic life until January 1929. At the meeting of May 10, 1929, the minutes record:

At the end of the discussion $\mathrm{Mr}$ Wittgenstein suggested that an old rule of the Club, that no paper should be more than seven minutes long, should be renewed. Most of the members present seemed to think that it would be desirable to set a time limit to papers, but that 7 minutes was too short. It was suggested that a motion suggesting a time limit should be proposed at the [next] meeting [...]. Mr Wittgenstein also suggested that the reading of minutes should be abolished.

At the next meeting, May 17, 1929, the minutes record: "Mr. Wittgenstein [...] pointed out that enough philosophical problems could be raised in twenty minutes to occupy the minds of the members of the club for the rest of the evening." Ultimately added to the rules was: "and it is therefore desirable that the papers should be as short as possible."

Drury (1984: 99) reports that H.A. Prichard gave a talk to the Moral Sciences Club in 1929 [no specific date given] on "Ethics". In the discussion afterwards, Wittgenstein made the point that "although two people could always discuss the best means to an agreed end, there could be no argument about what were absolute ends in themselves. Hence there could be no science of ethics." 
At the meeting on November 8, 1929, Mr. B. Moran read a paper entitled "Evidence for the Existence of Other Minds." Arthur MacIver (McGuinness 2016: 215) reports the title as "Evidence for the Existence of Other Minds according to Berkeley." The minutes laconically record that "a discussion followed." But MacIver reports (pp. 215-216):

Wittgenstein, who has no interest in anything historical, insisted on knowing what was Moran's own opinion and so started an argument which lasted all the rest of the evening. Wittgenstein holds that no statement has any meaning unless there is a logically possible test of its truth and that to share any one else's feelings is logically impossible, because they would then cease to be the other person's feelings, so that he was forced to hold that statements about other people's feelings only have meaning as statements about their behaviour, and on this he argued with Drury the whole evening. [...] At last the meeting was adjourned at eleven o'clock, but some of us stayed behind and the argument continued. Wittgenstein now saw that in some sense we can make statements about other people's feelings and mean something and he advanced a doctrine of a primitive experience which is no-one's experience, in which all individual experients somehow participate.

They finally ended the discussion at a quarter to twelve. But Moran's talk obviously proved fodder for thought, as Wittgenstein's first official contribution to the CMSC since his return was apparently a response to it.

\section{January 31, 1930, "Evidence for the Existence of Other Minds"}

The meeting was held in Dr. Broad's rooms, starting at 8:30 P.M. There were thirty-five members present. Prof. Moore was in the chair. The minutes record: "The minutes of the last meeting were read and adopted." While Wittgenstein's earlier suggestion about reading minutes had apparently not been accepted, minutes were now lamentably brief: "Dr. L. Wittgenstein spoke shortly on 'Evidence for the existence of other Minds'. A discussion followed." (Facsimile of the minutes in Nedo and Ranchetti 1983: 231.)

Wittgenstein arrived a bit late for the meeting. F. R. Leavis, the literary critic and Cambridge don, relates (1984: 63-64):

He dropped in one day very soon after lunch, and an unguarded polite reference I made to a paradox he had presented me with the last time 
we met started him discoursing earnestly and energetically, for it turned out that the paradox for him was pregnant and crucial.

Apparently, he continued developing the argument for the next six hours, during which time Leavis was hardly able to pay attention to him, which did not deter Wittgenstein.

I was dazed and tired and wanted him to go. Suddenly, at about eight o'clock, he realized the time and a pressing fact [...] . 'I'm talking to the Moral Science Club this evening. Come down with me.' [...] I heard afterwards that, apologizing for his lateness, he explained that he had been arguing all the afternoon with Dr Leavis.

MacIver reports on the meeting as follows (McGuinness 2016: 234):

Wittgenstein was down on the card to read a paper on 'Evidence for the Existence of Other Minds', but of course he never does read papershe talks until he dries up and then, when someone has set him going again, goes on talking. [...] I opened the discussion when Wittgenstein dried up for the first time but kept quiet after that, while the discussion went over the old familiar ground of tooth-ache and perhaps made the matter clearer than it has been before [...].

The meeting broke up at five minutes past eleven, people having begun to go away before that time.

On February 7, 1930, Richard Braithwaite gave a talk on "Time" (probably Braithwaite 1928). Apparently at one point Braithwaite "quoted poetry-Francis Thompson and Ronsard-and I am told", the student Arthur MacIver wrote (McGuinness 2016: 237), "that Wittgenstein mopped his brow in anguish, for he cannot abide the quoting of poetry in philosophical contexts." Wittgenstein's vivid reaction had to be reported to MacIver because "personally I was seated on the floor just under him and could not see his face." The official minutes from this Cambridge Moral Sciences Club meeting are regrettably brief, however, Fania Pascal notes in a memoir of Wittgenstein: "I remember a paper [at the Moral Sciences Club] given by Richard Braithwaite which Wittgenstein appeared to tear to pieces only to end up, to the amazement of all, by giving it his approval or maybe just letting it pass" (Pascal 1984: 16). 
Wittgenstein stopped going to CMSC meetings beginning in the fall of 1931. Apparently, this was because some people objected that he dominated the discussions (Wittgenstein 1995: 271, Wittgenstein's letter to Russell, apparently from November 1935). Fania Pascal, [[334]] who attended CMSC meetings during that time, recalls (Pascal 1984: 16):

Wittgenstein was the disturbing (perhaps disrupting) centre of these evenings. He would talk for long periods without interruption, using similes and allegories, stalking about the room and gesticulating. He cast a spell [...]. Once he said: "You cannot love God, for you do not know him", and went on elaborating the theme.

Wittgenstein was away from Cambridge academic life from the fall of 1936 to early 1938, living mostly in Norway.

By the fall term of 1938 Wittgenstein was again paying his subscription to the club. On November 10, 1938, Sir Arthur Eddington gave a talk to the club on "Prof. Stebbing's 'Philosophy and the Physicists"'. The meeting was held at Theodore Redpath's house. The minutes record: "The discussion consisted mainly of objections by Mr Watson and Dr Wittgenstein against Prof. E's view that all scientific knowledge is knowledge of structure, given by the relations between pointer-readings."

On December 1, 1938, Dr A. C. Ewing gave a talk to the club on "A Reply to Mr Wisdom on Meaninglessness.” The minutes record:

In discussion Doctor Wittgenstein said that he had never heard of the Verification Principle till about a fortnight previously. He knew about the method of asking the verification of propositions. The main point of asking the verification of some statement was to bring out distinctions. He did not like calling the statement that the meaning of a statement is the method of its verification, a principle. That made philosophy look too much like mathematics. There are no primitive propositions in philosophy.

Gasking and Jackson (1967: 54) attribute the following remark to Wittgenstein at a CMSC meeting. It seems likely it came from this meeting: 
I used at one time to say that, in order to get clear how a certain sentence is used, it was a good idea to ask oneself the question: "How would one try to verify such an assertion?" But that's just one way among others of getting clear about the use of a word or sentence. For example, another question which it is often very useful to ask oneself is: "How is this word learned?" "How would one set about teaching a child to use this word?" But some people have turned this suggestion about asking for the verification into a dogma — as if I'd been advancing a theory about meaning.

At the meeting on February 16, 1939, Mr. D. Prince gave a talk on "The Use of a Word." This provoked a response by Wittgenstein the following week.

\section{February 23, 1939}

The meeting was held in Yorick Smythies's rooms in King's College. Wittgenstein opened his talk by asking, "Why do philosophers often ask the meaning of some quite common [[335]] words?" He was partly responding to a talk given the week before by Derek Prince, in which Prince argued against the idea that the meaning of a word is equivalent to the use to which the word is put. Theodore Redpath's original minutes of the discussion of Prince's paper and then of Wittgenstein's paper are published in Wittgenstein 2003 (pp. 377380 ). These minutes give a vivid sense of how Wittgenstein managed to make his points through a fluid discussion that involved several people in attendance. Redpath's published account (Redpath 1990: 82-86) adds some details but omits others. The presentation lasted less than half an hour.

The next week, March 2, 1939, J.S. Boys Smith gave a talk to the Club on "Some Problems about Belief". Minutes from the talk as well as the discussion in which Wittgenstein participated are printed in Rhees 2015 (pp. 6-7). Then Rhees has notes of his own of the talk and Wittgenstein's contribution to the discussion (pp. 7-8). 


\section{February 2, 1940, "Causal and Logical Necessities"}

The meeting was held in Wittgenstein's rooms, with G. E. Moore in the chair. The minutes were taken by Casimir Lewy:

Prof. Wittgenstein gave a talk on Causal and Logical Necessities. The chief point of the talk was to show how a proposition which is originally based on experience and accepted as empirical comes to be regarded as necessary and analytic. The idea of causal necessity (or rather, an idea of causal necessity) was shown to be intimately connected with, and even due to, the conception of 'tracing a mechanism.'

The principle point of the discussion which followed was as to the meaning and use of the phrase 'self-evident,' e.g. when one says that some causal propositions or principles are self-evident.

On March 1, 1940, Yorick Smythies gave a talk to the Moral Sciences Club on "Mental Processes", for which Wittgenstein was in the chair. While the minutes, by Casimir Lewy, do not describe the "long discussion" which followed, there is a manuscript written by Smythies, titled "Wittgenstein's Reply to a Paper by Y. Smythies on 'Understanding"', which (apart from the title ascribed to Smythies' paper) fits the occasion in several ways. See Smythies (2017, Ch. 9) for the minutes and for the paper. The manuscript reads like a monologue in which Wittgenstein dominates, with occasional interjections or questions by Smythies and Lewy.

On May 23, 1940, Isaiah Berlin gave a talk ("in fear and trembling", Berlin 2015: 308) to the club on "Solipsism." The meeting was held in Timothy Moore's rooms in Trinity, with G. E. Moore in the chair. Berlin relates (Ignatieff 1998: 94):

After a few initial questions Wittgenstein became impatient and took over the discussion. [...] "No, no, that is not the way to go about it. Let me. Don't let's talk philosophy. Let's talk business with each other. Ordinary business. In ordinary circ[umstance]s, I say to you, 'You see a clock. The minute hand and the hour hand are both nailed to the clock face to certain ciphers. The whole face goes round, but the time remains the same.' No? That is solipsism."

\section{October 25, 1940, “Other Minds"}

Held in Timothy Moore's rooms in Trinity, with Lewy in the chair. The minutes were taken by Timothy Moore, secretary: 
Prof. Wittgenstein read a paper in which he discussed various problems connected with other people's minds. First he mentioned several of the answers which have been given to the question "How do we know of the existence of other people's minds?", and explained why he considered the analogical argument to be unsatisfactory. Then he discussed the nature of this question itself; and, among other things, described at some length the sort of circumstances [[336]] under which he would wish to say that a person did not believe that other people had minds, or did believe that flowers felt.

A discussion followed.

Notes of this talk were also taken, in German, by Rose Rand (Rand 2004: 103).

On January 24, 1941, G. H. Hardy gave a talk to the club on "Mathematical Reality", sections 20-22 of his book $A$ Mathematician's Apology (Hardy 1992). The meeting was held in C. D. Broad's rooms. Mays (1967: 82) recalls: "Hardy mentioned that he did not accept Wittgenstein's view that mathematics consisted of tautologies. Wittgenstein denied that he had ever said this, and pointed to himself saying in an incredulous tone of voice, "Who, I?"

While Wittgenstein gave no talks to the club for the next four years, he was elected chairman three times, in 1941-1942 (replacing Moore after nearly thirty years), 1942-1943, and 1943-1944. Some unpleasantness arose in November 1944 over his not having been informed of his nomination for re-election, and a resolution of apology was passed unanimously.

\section{February 22, 1945}

The meeting was held in R. B. Braithwaite's rooms in King's College, with Braithwaite in the chair. Minutes simply record: "Prof. L. Wittgenstein opened a discussion."

Continuing the long-standing debate about length of papers, the minutes for May 17, 1945, record: "Prof. Wittgenstein suggested that in future people who were invited to 'read papers' to the Club should be sent a standard note which did not in any way suggest they should 
read elaborate papers." And again on May 31, 1945, the minutes record:

Prof. Wittgenstein proposed that the following be sent to all people invited to open discussions: "We should be very grateful if you would open a discussion at the Cambridge Moral Science Club on...... . The purpose of the club is to discuss problems of philosophy. In our experience only a very small number of points can be dealt with thoroughly in an evening. Therefore short papers, or a few opening remarks stating some philosophical puzzle, tend as a rule to produce better discussions than long and elaborate papers, which are difficult to digest at a single hearing." This was unanimously accepted.

The form of invitation was later to create some difficulties (see Popper's talk, p. 22 infra).

\section{October 25, 1945}

The meeting was held in Braithwaite's rooms in King's College, with Wittgenstein in the chair. Minutes, taken by secretary G. E. M. Anscombe, record that:

Professor Wittgenstein opened a discussion on Professor Moore's paradox: "P, but I don't believe P." He maintained that the problem raised by this utterance was not to be solved by [[337]] regarding it as a piece of inconsistent behaviour; nor could it be said simply that it must be a lie, for even if it was a lie the absurdity remained. We should rather consider the asymmetry of psychological expressions such as "know", "believe" and so on: i.e. the asymmetry between their use in the first person present and in other persons or tenses, or in suppositions. Professor Moore was present and finally said that though he agreed that the utterance was absurd, it might nevertheless be true, for it might both be true that $\mathrm{p}$, and that I did not believe $\mathrm{p}$.

At the November 29, 1945, meeting Moore himself then gave a talk on "P, but I do not believe P." The minutes contain no mention of Wittgenstein. (It seems likely that a hand-written manuscript for this talk is Moore 1993b: 207-212.)

At the December 6, 1945, meeting, held in Braithwaite's rooms, with Wittgenstein in the chair, Anscombe's minutes record that an 
impromptu discussion [...] was held on the question "Did the world have a beginning in time?" First it was asked whether, if the world were supposed to have begun 3 years ago, the expression " 4 years ago" were senseless. Professor Wittgenstein compared the status of the date " 3 years ago" to that of the velocity which is the velocity of light. The expression "4 years ago" would not be absurd, any more than the expression "310 thousand kms. per second"; but given that " 3 years ago" was assigned as the date of the beginning of the world, then it is absurd to ask what happened 4 years ago; though it would be a mistake, not an absurdity to say that the world began four years ago.

The discussion turned later on the status of a dispute about whether the world had a beginning in time.

On March 14, 1946, with Wittgenstein in the chair, the club continued an impromptu discussion of Ayer's interpretation of Cogito Ergo Sum: "Professor Wittgenstein argued about the importance of the gesture with which one points to oneself, and sketched out the circumstances in which one might no longer do so, and so no longer feel the force of Descartes' argument." (See also Wittgenstein's discussion of Wood's paper: 68-70 infra.)

On October 25, 1946 (Edmonds and Eidinow 2001: 281-82), Karl Popper gave a talk on "Methods in Philosophy" (as titled in the minutes). Braithwaite was in the chair. Popper (1974: 97) reports that

I received an invitation from the Secretary of the Moral Sciences Club at Cambridge to read a paper about some "philosophical puzzle". It was of course clear that this was Wittgenstein's formulation, and that behind it was Wittgenstein's philosophical thesis that there are no genuine problems in philosophy, only linguistic puzzles. Since this thesis was among my pet aversions, I decided to speak on "Are There Philosophical Problems?”. I began my paper ([...] in R. B. Braithwaite's room in King's College) by expressing my surprise at being invited by the Secretary to read a paper "stating some philosophical puzzle"; and I pointed out [[338]] that by implicitly denying that philosophical problems exist, whoever wrote the invitation took sides, perhaps unwittingly, in an issue created by a genuine philosophical problem.

The confrontation that followed between Popper and Wittgenstein has been the subject of much speculation and disagreement. The secretary, W. Hijab, merely noted that "the meeting was charged to an unusual degree with a spirit of controversy." (See also 
contributions by Geach and by Munz in Flowers and Ground 2016: 741-744.)

In a letter to Rhees two days later Wittgenstein wrote (2008: 403):

On Friday I $[\ldots]$ attended a Moral Sc. Club meeting from 8:30-11, a lousy meeting, by the way, in which an ass, Dr Popper from London, talked more mushy rubbish than I've heard for a long time. I talked a lot (as usual) and felt no bad effects [considering that he had a cold].

The stage had been set for another talk by Wittgenstein three weeks later.

\section{November 14, 1946, "Philosophy"}

The meeting was held in Braithwaite's rooms, Gibbs Hall H3 in King's, with Ewing in the chair and Hijab as secretary. Wittgenstein wrote to G. E. Moore (Wittgenstein 1995: 324, dated November 14, 1946) in part: "I'm giving a talk, roughly, on what I believe philosophy is, or what the method of philosophy is." Minutes and notes for this talk (and the one by Popper) are published in Wittgenstein 2003 (pp. 397-399).

Some five months later (April 24, 1947) A. C. Ewing gave a paper, "Impossibility of Metaphysics?" with Wittgenstein in the chair. (A version of this paper was published as Ewing 1948.) In this paper, as published, Ewing defends metaphysical statements against the usual verificationist criticisms. The published paper has clearly been modified to take account of some of Wittgenstein's comments. While the club minutes note nothing more than that the meeting was in Braithwaite's rooms, extensive notes of the discussion between Ewing and Wittgenstein were kept by Gilbert Harris Edwards (1946-1947):

Wittgenstein said that not all statements were empirically verifiable. Thus mathematical propositions and psychological propositions in the first person came under this heading. Wittgenstein said that it was important to ask the verification questions of any question. Also he objected to the hack phrase of "Verification Principle." Ewing said that Positivism excludes Theological propositions. To this Wittgenstein replied that - it was nonsense to say that such propositions were 
meaningless - what we wanted to know was how they were used, how the theologians talked among themselves.

Wittgenstein was asked if he could say what the character of metaphysical statements was and why he ruled them out. In reply he said that the characteristics of a Metaphysical statement, insofar as one could be given at all, was the empirical air, the pseudo empirical character. They are put in such a way as to make us think we could experiment to find ou[t] more about them.

E.g. Is space absolute or relative? He cited the fact that he once walked about trying to experiment upon idealist statements.

But he said that Metaphysical statements were a family and this was first known. Concerning the question as to why they were rejected he said it was very hard to answer with no particular case on hand. To illustrate he cited an old controversy from medicine where 'homeopathy' [[339]] (treatment of diseases by drugs—something like the disease) and 'allopathy' (treatment of a disease by introducing a different tendency [...]) were debated. Nowadays if anybody were to say "which?" the answer would be "This isn't a question", or "Study medicine."

An example of a Metaphysical question was the Ontological argument: Ewing said that anybody could have a present of this since existence was not a predicate. Wittgenstein now took up the question as to what was meant by saying that existence was not a predicate and why it sufficed to refute the Ontological argument. A more simple example was given of one who said that Dragons did not exist, but in order to predicate [non-?] existence of them they must exist in some way. To refute him Ewing said we point out that existence is not a predicate. But Wittgenstein queried this asking whether the man would appear illuminated afterwards. He said that if somebody said "Man is 100 " and we told him that " 100 " was not a predicate of man, we were doing a similar thing. If a person were so stupid as to talk like that we could hardly expect our words to have great effect. What use is the answer? Wittgenstein said that it was of course important to say that we did not predicate 100 of a man, but not in this respect. We should ask what we are saying when we say existence is not a predicate.

Ewing said that the positivists claimed that there was no real difference in the metaphysical systems, but only a difference in the way people talked about the world. Now since one was supposed to be better than another on the ground that it was more illuminating or something it may be asked on what ground one was preferred to another.

Wittgenstein asked Ewing if the fact that one did not lead to contradictions whereas the other did was not enough. No reply. 
Wittgenstein then said that to call a difference in Metaphysical systems a mere difference in way of talking was quite misleading-like saying that the difference between two suits was a difference in tailoring. There is also the difference in attitude, in the way we looked at the world and our problems.

The Moral Sciences Club meetings exposed Wittgenstein to a number of papers by influential thinkers beyond his current colleagues and students. Wittgenstein is known to have been present for the following notable papers (either because they were in his rooms, or he was in the chair, or the minutes indicate his involvement in discussion):

Gilbert Ryle, “The Program of Phenomenology", November 29, 1929. (McGuinness 2016: 226-227)

G.E. Moore, “Certainty”, April 21, 1939. (See Moore 1993 a. Wittgenstein was not present for this meeting-it was a "starred meeting" to which faculty were not allowed. But Moore read the paper to Wittgenstein subsequently during Moore's “athome" on May 2. An account of their extensive discussion can be found in Citron 2015.)

A. J. Ayer, "Sense Data and Incorrigible Propositions", May 19, 1939.

Gilbert Ryle, "Philosophers’ Arguments”, January 26, 1940.

Isaiah Berlin, "Solipsism”, May 23, 1940.

M. H. A. Newman, "Formalism and Logic", November 15, 1940.

A. J. Ayer, Discussion of The Foundations of Empirical Knowledge, February 12, 1941. (Notes in Rand 2004: 134-135)

C. H. Waddington, "Scientific Empiricism”, May 1, 1941.

G. E. Moore, "Certainty”, October 26, 1944.

Bertrand Russell, "Proper Names”, January 25, 1945.

C. D. Broad, "Leibniz and Clarke on Absolute versus Relative Space", January 24, 1946. 
A. J. Ayer, "Causality", May 30, 1946. [[340]]

K. R. Popper, "Methods of Philosophy", October 25, 1946.

J. L. Austin, "Nondescription", October 31, 1946. (cf. MS 133: 13r, November 1, 1946: 'Yesterday 'Moral Science Club': I myself conceited, and stupid as well. The 'atmosphere' miserable.- - Should I go on teaching?”)

H. H. Price, "Universals and Resemblances", November 29, 1946. (Letter from Wittgenstein to Moore, December 3, 1946, comparing Austin and Price at CMSC.)

At a meeting on May 29, 1947, after a paper by Malcolm, but for which it is not recorded whether Wittgenstein was present, there was a "16-12 vote in favor of Braithwaite's motion that in future one or two long papers be read each term, to which a reply could be read by someone [...]." It was decided this would be given a year's trial before permanent adoption. There is no indication that Wittgenstein attended any further meetings.

\section{Cambridge University Lectures}

In January 1929, Wittgenstein returned to Cambridge after a fifteenyear absence. He conducted research for all three terms of that year, and he was granted a Ph.D. in June 1929. On October 16, 1929, the faculty board of moral science resolved that he should be invited to give a course of lectures to be included in the lecture list for the Lent term of 1930. (Lent term runs ten weeks from late January to March; Easter term, sometimes called "Summer" or "May" term, runs eight weeks from April to June; Michaelmas term runs ten weeks from October to December.)

In a conversation witnessed by S. K. Bose (1978), Wittgenstein was asked by Braithwaite under what title his courses should be announced. After a long silence Wittgenstein replied: "The subject of the lectures would be philosophy. What else can be the title of the lectures but Philosophy." This title was used thereafter for all his courses as announced in the Cambridge University Reporter, except for the 1932-1933 lectures: "Philosophy for Mathematicians." 
On October 22, 1929, Wittgenstein reflected, in code, in his notebook (Wittgenstein 1993-1996, vol. 2: 102; MS 107: 175-176): "Having real problems and I'm so unclear that I can't write down anything proper. Supposed to hold lectures in the next two terms. Am doubtful how it will go. The main thing would be that my work move forward well now." Later he encountered an unexpected impediment (Wittgenstein 2003b: 57, October 16, 1930):

I cannot work for myself yet [during the Michaelmas term] \& that is in part due to the conflict in me of the English and German modes of expression. I can really work only when I can continuously converse with myself in German. But for my lectures I must now arrange things in English \& am thus disturbed in my German thought; at least until a peaceful accord has formed between the two \& that takes some time, perhaps very long.

Wittgenstein continued lecturing at Cambridge on a fairly regular basis, except for various leaves of absence, through the Easter term of 1947.

\section{Lent 1930 (L30); Easter 1930 (E30)}

Wittgenstein's friend Frank Ramsey died on January 19, 1930 (Monk 1990: 288-289). The first lecture was the next day-Monday, January 20. Wittgenstein's diary notation of [[341]] the first lecture is: "5-6 Vorlesung" with plans to meet "Gil" Pattison afterward (printed in facsimile in Nedo and Ranchetti 1983: 234).

Desmond Lee's notes (Lee 1980: 1) of the opening lecture begin as follows:

Philosophy is the attempt to be rid of a particular kind of puzzlement. This "philosophic" puzzlement is one of the intellect and not of instinct. Philosophic puzzles are irrelevant to our every-day life. They are puzzles of language. Instinctively we use language rightly; but to the intellect this use is a puzzle.

Later that first day Wittgenstein reflected: "Held my first regular lecture today: so, so. I think that it will go better next time.-if nothing unforeseen comes up" (Wittgenstein 1993-1996, vol. 2: 174; MS 107:247).

Lectures were held once every week-Mondays at 5:00 P.M., lasting for about an hour, in an ordinary lecture room in the 
University Arts School. Discussion class, lasting at least two hours, was Thursdays at 5:00 P.M., at first in the lecture room but soon in Priestly's set of fellow's rooms in Clare College. Later the lectures were also moved to Priestly's rooms and they began to last longer as well (Moore 1993: 49).

Lectures and discussions were attended by about fifteen people - a mixture of undergraduates and graduates, including Desmond Lee, S. K. Bose, Maurice O'C. (Con) Drury, Max Black, Patrick DuVal, D.G. James, David Hayden Guest, Maurice Cornforth, Austin Duncan-Jones, Arthur MacIver, John Cooley, and someone named Middleton. G. E. Moore was regularly present, and occasionally other dons such as Richard Braithwaite.

Students' notes for (L30) are published in Lee 1980, pages 1-14; and notes for (E30), pages 15-20. Moore's summary of his lecture notes (Moore 1993) is organized more topically than chronologically. Nevertheless, in his own style of organization he refers to terms (L30) and (E30) as "(I)." Moore's original notes, from which the summarized notes were drawn, were only taken in the Monday lectures and are published as Wittgenstein 2016a (L30 is pp. 3-37 \& E30 is pp. 41-63). Interesting recollections, though not really notes, by MacIver, for (L30) only, are in McGuinness 2016. Moore reports (1993: 50): "I remember Wittgenstein once saying to me that he was glad I was taking notes, since, if anything were to happen to him, they would contain some record of the results of his thinking."

The atmosphere of Wittgenstein's lectures was perhaps well captured by I. A. Richards (1972) in his poem "The Strayed Poet". Lee (1979: 214) recalls that the lecture

was itself of a very informal nature, and liable to break off into discussion. He had no kind of system or technique, but simply talked about problems that were in his mind. [...] The discussions were not so very dissimilar from the lectures [...]. Though Wittgenstein preferred discussion to lecture as being less formal and allowing a train of thought to be followed more easily, he completely dominated any discussion in which he took part, and these discussions associated with his lectures were largely a monologue, the problem being to find a question or problem to get him started and to provide an occasional interjection to keep him going. 
However, another student, Maurice Cornforth had a different experience (Cornforth, 1939: 95-96):

A circle of young students quickly gathered around [Wittgenstein], and both David [Guest] and I belonged to that circle. We used to sit at Wittgenstein's feet, drinking in his new ideas, and at the same time we argued furiously, both with him, and with one another. This went on for a whole year.

Lee notes (p. 218) that Wittgenstein relied on Moore "a good deal to help in his discussion classes by making the comment that would set or keep the ball rolling." "Wittgenstein always had a blackboard at both lectures and [discussions] and made plenty of use of it" (Moore 1993: 49).

In his diary (2003b: 21, May 2, 1930) Wittgenstein worried that "in my lectures I often seek to gain favor with my audience through a somewhat comic turn; to entertain them [[342]] so that they willingly hear me out. That is certainly something bad." And later (p. 37, May 12, 1930):

Before my lectures I am always anxious even though so far it has always gone quite well. This fear then possesses me like a disease. It is by the way nothing other than test anxiety. The lecture was mediocre. It's just that I am already tired fsine I didn't hone of my listeners has any idea how much my brain must work in order to achieve what it achieves. If my achievement is not first rate, it is still the outer limit of what I can achieve.

Drury (1984: 118) records a conversation with Wittgenstein, probably during the time of these lectures:

I think in your recent lectures you have been directly concerned with Kant's problem: how are synthetic a priori propositions possible? Wittgenstein: Yes, you could say that. I am concerned with the synthetic a priori. When you have thought for some time about a problem of your own, you may come to see that it is closely related to what has been discussed before, only you will want to present the problem in a different way.

\section{Michaelmas 1930 (M30); Lent 1931 (L31); Easter 1931 (E31)}

In (M30) and (L31) lectures were Mondays at noon, and discussion was moved to Fridays at 5:00 P.M. According to Moore (1993: 49) 
lectures and discussions continued to be held in Priestly's rooms for all these terms (not switching to Wittgenstein's new rooms in Whewell's Court in Trinity College until October 1931). But King (Lee 1980: xii) claims Wittgenstein began holding lectures and discussions in his own rooms in Whewell's Court in Easter term, 1931. (However, compare Britton's preferable account below: 31 infra.) In any case, note taking became much more difficult in (E31) — apparently because of a more informal setting.

Preparing for the first lecture in (M30) Wittgenstein wrote in his diary (2003b, October 8, 1930):

It is 3 weeks since I thought of philosophy, but every thought of it is so foreign to me as if I had not thought such things for years. In my first lecture I want to speak about the specific problems of philosophy \& have the feeling: how can I say anything about this, I don't know them anymore.

The first class was held on Monday, October 13. Lecture notes (Lee 1980: 21) open with: "The nimbus of philosophy has been lost. For we now have a method of doing philosophy, and can speak of skilful philosophers." Early in the L31 term Wittgenstein wrote in his diary (2003b: 71; February 7, 1931): "I need an extraordinary amount of energy in order to hold my classes. I see this when I am lax in the slightest \& immediately incapable of preparing myself for the lecture."

Among the students were Desmond Lee, John King, Raymond D. Townsend, John Inman, M. O’C. Drury, D. G. James, W. H. Watson, A. J. Shillinglaw, J. B. Nansen, Karl Britton, and S. K. Bose. King (n.d.) also adds: "M[aurice] Cornforth (and occasionally his future wife Miss K[itty] Klugman), and J. Bronowski (about twice)." Also I.A. Richards attended rarely.

Notes for (M30) are pages 21-41, notes for (L31) are pages 4259, and notes for (E31) are pages 60-64 in Lee (1980). Moore (1993) referred to these terms as "(II)" in his topical account. Notes by King (1930-1931), Townsend (1930-1931), and Inman (1931) are extant. Moore's full chronological notes are Wittgenstein 2016a: M30 is pp. 67-99; L31 is pp. 103-136; and E31 is pp. 139-173. 


\section{Michaelmas 1931 (M31); Lent 1932 (L32); Easter 1932 (E32)}

In a letter to Moore (Wittgenstein 1995: 250-51, dated August 23, 1931) Wittgenstein requests to be relieved of lectures for the Michaelmas term "to reserve all my strength for [[343]] my own work." McGuinness and von Wright claim (1995: 250) that he gave no lectures that academic year, which is confirmed by the Cambridge University Reporter. Moore (1993: 49) claims that lectures resumed in (E32). In any case, Wittgenstein continued to hold discussions on Fridays from 5:00 P.M. to 7:00 P.M. for the whole academic year. Nedo (Wittgenstein 2000: x) claims they were "unpaid discussion classes for interested students."

Discussions (during M31) were held in Wittgenstein's rooms, H4 Great Court, in Trinity College, changing to his rooms in Whewell's Court after Christmas (Britton 1954: 709-10; Goodstein 1972: 272). Although Lee and Moore both hold that Wittgenstein was, by Michaelmas term, teaching in his rooms in Whewell's Court, this cannot be so. In his diary (2003b: 125) notation for November 7, 1931, Wittgenstein complains of the noisy students who live above him. But his rooms in Whewell's Court were at the top of the stairsK10. (It seems likely, therefore, that classes for (E31) were also held in H4 Great Court.) The rooms in Whewell's Court were the ones Wittgenstein had had in 1912-1913 (Moore 1993: 49).

Ten to fifteen would attend the discussions, including Moore, and occasionally some other dons (Lee 1980: xiv). Britton estimated the number at twenty. King (n.d.) recalls, in addition to himself and Moore, A. C. Ewing, Karl Britton, David Haden-Guest, Francis Skinner, Goldstein, "Sprague (a very short-sighted American), and R. B. Braithwaite (fitfully, and with Miss [Margaret] Masterman, whom he was to marry)." Britton (1966) adds to this Con Drury, A.R.M. Murray, Maurice Cornforth, Arthur Shillinglaw, Prof. Hardy, H.P.D. Lee, and Austin Duncan-Jones. Braithwaite contributed an article to Cambridge's University Studies (1933), that appeared in March 1933, in which he described Wittgenstein's views in the Tractatus and how they had changed since he returned to Cambridge. Wittgenstein took vigorous exception to this account of his views (1993c). R.L. Goodstein says (Goodstein 1966) that he attended lectures from 1931-1935, and recalls also in attendance during (some 
part of) that period Dennis Lloyd (Baron Lloyd of Hampstead) and Terence Wilmot Hutchison.

Notes for (M31), (L32), and (E32) are on pages 65-108 in Lee 1980. Moore's full chronological notes (Wittgenstein 2016a: 155173) have notes only for (E32).

In preparatory notes written (in English) in a pocket notebook Wittgenstein described his teaching method (MS 155: 36v-38r; Wittgenstein 1993-96, v. 3: vii):

What I should like to get you to do is not to agree with me in particular opinions but to investigate the matter in the right way. To notice the interesting kind of things (i.e. the things which will serve as keys if you use them properly.

What different people expect to get from religion is what they expect to get from philosophy.

I don't want to give you a Def. of Philos. but I should like you to have a very lively idea as to the characters of philosophic problems. If you had, by the way, I could stop/start/ lecturing at once.

To tackle the phil. problem is difficult as we are caught in the meshes of language.

"Has the universe an end/beginning/ in Time" (Einstein)

You would perhaps give up Phil. if you knew what it is. You want explanations instead of wanting descriptions. And you are therefore looking for the wrong kind of thing.

Philos. questions, as soon as you boil them down to ... change their aspect entirely. What evaporates is what the intellect cannot tackle.

In his notebook on November 22, 1931, Wittgenstein wrote (MS 112: 223; Wittgenstein 1980/1998: 17/25): "Someone who teaches philosophy nowadays gives his pupil foods, not because they are to his taste, but in order to change his taste."

In student notes for this year we find Wittgenstein saying (Lee 1980: 66): "The meaning of a proposition is its mode of verification" and "the meaning of a word lies [[344]] entirely in its use." Goodstein (1972: 272-273) recalls the very first discussion of (M31). Wittgenstein

was talking about a rope that we were to imagine had one end in the room, and stretched out of the window and across Great Court with its other end out of sight. Someone was measuring the rope, following it foot by foot from its end in the room. Suppose that no matter how far 
the rope was followed the end was not found, could we ever say that the rope was infinitely long? Did it make any sense to say that rope was infinitely long? Could we devise a test to find if it was infinitely long? Of course, so long as the criterion was that of following the rope it made no sense to say the rope was infinitely long; we could decide if it was or was not longer than any chosen length, but there was no outcome to the attempt to measure the rope which would lead us to say that the rope was infinitely long. Was there then no sense in talking about an infinitely long rope? Imagine that we devised a machine which when applied to one end of the rope indicated the length of the rope by means of the angle through which a pointer on a dial turned, the length being proportional to the tangent of the angle turned through. Suppose we now applied the machine to a particular piece of rope and the pointer turned through an angle of ninety degrees, would we not now say that the rope was infinitely long?

Goodstein also recalled from this same class (1972: 284):

Wittgenstein said that you can invent a machine that will not work but you cannot invent a game that will not work. This sums up the difference between physical and logical possibility in a nutshell. [...] The design [of a machine] itself cannot tell you if it will work [...]. But if you invent a game, you invent the rules of the game; the rules may be inconsistent, but if this is so it shows itself in the rules (and there is nothing that needs to be put to the test of experience).

Britton (1967: 56-57) gives an account of the atmosphere of these discussions:

On the whole Wittgenstein was tremendously impatient in his discussion: not impatient of the raw newcomer to philosophy, but of the man who had developed philosophical views of his own. Wittgenstein talked often standing up and walking excitedly aboutwriting on the blackboard, pointing, hiding his face in his hands. But the most characteristic of all his attitudes was a very quiet, very intense stare-suddenly adopted and leading to a slow deliberate utterance of some new point. Very often he got thoroughly "stuck": appealed in vain to his hearers to help him out: he would walk about in despair murmuring: "I'm a fool, I'm a fool." And such was the difficulty of the topics he discussed, that all this struggle did not seem to us to be in the least excessive. 


\section{Michaelmas 1932 (M32) \& (M32m); Lent 1933 (L33) \& (L33m); Easter 1933 (E33) \& (E33m)}

During this academic year, Wittgenstein gave two sets of lectures: one set on his regular topic of "Philosophy" and another set called "Philosophy for Mathematicians" marked as (...m). The regular class had lectures on Mondays at 5:00 P.M., and discussions on Fridays at 5:00 P.M. The class for mathematicians met Wednesdays at 5:00 P.M. All the classes, from here through 1936, met in K-10, his sparsely furnished rooms at the top of the stairs in Whewell's Court. [[345]]

Those attending lectures in this period included Alice Ambrose, Charles Stevenson, occasionally I.A. Richards, Mary Cartwright, Harold Ursell, L.C. Young, Francis Skinner, Helen Knight, J.O. Wisdom, and of course G.E. Moore.

Ambrose (1972: 13) says that "during the first term [M32] I felt that I was hearing a lecture in which there were gaps, such as intermittent deafness might produce." She goes on to say "few questions were raised, though he tried desperately to grasp their point, sometimes by the disconcerting procedure of threading his way through the chairs brought into his rooms [...] to confront the questioner at close quarters." In a letter of October 16, 1932, Ambrose writes (MS Add.9938, Cambridge University Library): "He is extremely hard to follow; he forgets what he set out to say, rears ahead of himself-says Whoa! [...] settles down rigidly then and thinks with his head in his hands, stammers, says 'Poor Miss Ambrose', swears, and ends up with 'It is very diff-i-cult'."

Notes for (M32), (L33), and (E33) are on pages 3-40 in Ambrose 1979. Moore (1993) refers to his summary notes for classes during these terms as "(III)", though that also includes notes from (E32). Moore's full chronological notes are in (Wittgenstein 2016a): M32 is pp. 177-223; L33 is pp. 227-304; and E33 is 307-365. E33 includes a sustained discussion of ethics, aesthetics and Frazer's Golden Bough. Notes for the lectures for mathematicians are on pages 205-225 in Ambrose 1979. Because they are so short and seem to be divided into eleven lectures, it seems unlikely that they cover a year-long course. It is possible that they constitute, instead, the initial lectures for the eventually cancelled class for mathematicians during 
Michaelmas 1933 (a possibility suggested in a letter from Ambrose to the author).

There is a letter from Wittgenstein to a mathematics student and Fellow of Girton Hall-Mary Cartwright_-(published in facsimile in Nedo and Ranchetti 1983: 258), in which Wittgenstein comments on his class process. Though the letter is dated only "Saturday", its reference to class on "Wednesday" suggests it concerned the class for mathematicians this academic year:

Thanks very much for your letter and the paper on 'Number'. I wonder if you would allow me to discuss it next Wednesday in our class. It would come in very useful indeed. It's the only way of getting anything out of these classes to try to formulate your thoughts on a subject yourself. + then have them pulled to bits. For if they can stand the pulling, all the better. I can't pick holes if there aren't any. In case you don't object to my discussing your paper on Wednesday, please don't bother to reply.

There is a long footnote appended to this letter in its publication by McGuinness (Wittgenstein 2008: 207) where McGuinness recounts impressions from a number of people who attended Wittgenstein's lectures during this period.

L.C. Young, a mathematician and Fellow of Trinity College at the time, recalled his experience in Wittgenstein's class for mathematicians (Young 1981: 63-64). However, not everything he says sounds fully reliable:

I once listened for a whole year to the mathematical philosopher Ludwig Wittgenstein. [...] At the beginning of the academic year, no less than 100 people turned up: I was lucky to have arrived first, and to secure a seat. The others crammed themselves into the room, and all the way down the stairs... We agreed that the next meeting would be in my own palatial Fellow's rooms in Neville's Court. However after a few meetings, Wittgenstein insisted on a return to his own rooms, and in this way he succeeded in reducing his audience to about 40 . In the course of the year, the audience dwindled further, until at the end only my friend Ursell and I were left.

Wittgenstein's was an amazing performance. [...] I probably learnt as much from him as from any of my teachers. But let me describe what actually took place. Wittgenstein addressed himself almost entirely to a single paragraph in Hardy's Pure Mathematics [...]. The paragraph Wittgenstein selected had to do with irrational numbers. I knew Hardy 
well: he had excellent qualities, quite apart from his mathematics and his great reputation, but he was a confirmed nominalist- he felt entitled to make up any definition he pleased. He was an easy target for Wittgenstein. The odd thing is that Wittgenstein never attacked him! On the contrary, he tried very hard to understand that paragraph-he tried for a whole year.

Much of the time he stood in front of his little trestle blackboard, with his mouth open. At other times he would talk quite volubly. I can only say that it kept me thinking hard, with my brain racing furiously, trying to disentangle all manner of difficulties that I had never before dreamt of, or more often to imagine what difficulty could possibly be stopping him in mid-sentence at this particular point. One such difficulty concerned the equation $\mathrm{a}=\mathrm{b}$. If $\mathrm{a}$ and $\mathrm{b}$ are equal, why not use the same symbol for both? However in that case the equation becomes $\mathrm{a}=\mathrm{a}$, and this cannot be denied, and is consequently meaningless. To have a meaning, it must have a contrary which is thinkable; if it has no meaning, it should be eliminated.

Young is also mentioned in Moore's notes of (L33) (p. 268), which suggests he attended at least some of Wittgenstein's regular lectures as well.

\section{Michaelmas 1933 (M33) \& (M33m); Lent 1934 (L34); Easter 1934 (E34)}

The Cambridge University Reporter announced the continuation of the class for mathematicians and Wittgenstein's regular class (vol. 63, June 29, 1933: 1322; vol. 64, October 2, 1933: 62). To the former, according to Ambrose (1967a: 148): "30 to 40 people turned up, which distressed [Wittgenstein]. After three or four weeks of lecturing he turned up at lecture and told the class he couldn't continue to lecture." Instead he proposed to give dictations to a select group of students (and have them distributed to the rest of the class?). The Reporter later acknowledged (vol. 64: 522, 786) that only the regular philosophy class was taught each term. Ambrose recalled that about a dozen students attended it (1967a: 149).

While no notes are known to derive from the regular class during this year, Rush Rhees offered a glimpse. Rhees was a regular student and friend of Wittgenstein beginning in 1935, but he in fact attended a few classes in (M33) and reported on them in a letter of November 5, 1993, to a former teacher (Erbacher 2016: 3-4): 
I went to Wittgenstein a few times. He very much gives me the impression of being a straightforward and honest person; however, I don't think that I will go to him more often. I did not make this decision instantly, as Moore seems to be very appreciative of Wittgenstein. I, in turn, value Moore's judgment very highly, and I know that he would not have his opinion without a reason. Nonetheless, I think I will not go anymore. I find his style of lecturing confusing. He never preparesand when he does, his lectures suffer. (I am convinced that he is no posturer in this, although he is probably mistaken.) He continuously speaks in similes (which are only partly actual examples), and says about himself that he always thinks in similes. If something does not become clear, he does not try to give an explanation in simple words but instead looks for a new simile. This method, though, is in accordance with his philosophical position, according to which the answers to the most important philosophical questions cannot be given through propositions or theories, but can only be "shown" by means of similes or "symbolic forms". Therefore, he says that he may be the right man for philosophy. (This is again, I believe, only naivety, not a sign of vanity.) But this is why his lectures do not get show a clear thread. Currently he lectures on the philosophy of language, particularly on the idea of meaning. He constantly emphasizes that the matter is exceptionally difficult. Sometimes he grabs his head, giving the explanation, "All this is tremendously difficult, we are in the middle of hell right now." And I asked myself if some of the attendees have any clear impression about philosophy, barring that the whole (quite undefined) matter is "tremendously difficult". This I regard as pedagogically bad. I hear that only after having heard him for a fairly long time one starts to recognize how much one gets from him. That I am willing to believe. But life is short $[\ldots]$

Wittgenstein's dictations were made to H. M. S. Coxeter, R. L. Goodstein, Francis Skinner (all mathematicians), Margaret Masterman Braithwaite, and Alice Ambrose (a philosopher with mathematical interests). Dictations began on November 8. Within a month Mrs. Helen Knight and another (Robert Martineau?) were added; Coxeter left after the first term. In a letter to Moore at the end of the first term (1995: 256) Wittgenstein says that he had dictated twice a week - ten times that term and anticipated dictating perhaps three times a week for the rest [[346]] of the year-about fifty-two dictations altogether. He also estimated the cost of printing 
fifteen copies. Eventually copies were made, bound in blue paper. The volume came to be called the "Blue Book." A letter from Wittgenstein to Coxeter (dated Monday Jan. 22 ${ }^{\text {nd }}$ [1934]; copy in von Wright and Wittgenstein Archives, Helsinki) includes: "I shall have all my classes in my own room this term as they are all small 'dictating classes'. Thank you very much for allowing me to have them in your rooms last term. I will eventually fetch back my blackboard etc." Seemingly he is characterizing his (L34) as a "dictating" class as well as the Blue Book group.

In the Blue Book Wittgenstein's important notions of "language game" and "family resemblance" begin to take shape. Wittgenstein sent a corrected copy to Russell some two years later (1995: 269-70), warning him that "I think it's very difficult to understand them, as so many points are just hinted at. They were meant only for the people who heard the lectures" (a surprising disclaimer, since they were originally supposed to substitute for hearing the lectures!). A facsimile of the first page of Skinner's copy, with corrections, is reproduced in Nedo and Ranchetti (1983: 269). Other copies were distributed as well, some reaching people Wittgenstein had not intended. (A copy from Robert Thouless, with additions in Wittgenstein's hand, was recently donated to the Wren Library. See Smith, 2013: 40-45.)

Though the preponderance of mathematicians among the students taking dictation suggests they came from the class for mathematicians, the material dictated in the Blue Book could hardly be thought to substitute for a course on philosophy for mathematicians. Additional notes from Wittgenstein exist from this year and have been labeled the "Yellow Book." Among the selected parts published by Ambrose (1979), a portion is labeled as notes taken by Ambrose on lectures that Wittgenstein gave before canceling the formal lectures (pp. 43-55), and the rest are notes from informal discussions that occurred after the formal lectures were canceled, in intervals between dictations for the Blue Book (pp. 5673). But the first portion could hardly be notes from the soon to be canceled course for mathematicians, since it is altogether nonmathematical, as are the Blue Book and the rest of the Yellow Book. Furthermore, no notes seem to exist from the uncanceled 
"Philosophy" course. Additional notes exist from the Yellow Book discussions by Masterman (about 100 pages, in private hands). After Francis Skinner's death in 1941, Wittgenstein sent to R. L. Goodstein a cache of papers he had dictated to Skinner. In 2002 they were deposited at the Wren Library, Cambridge (Gibson 2010). They are currently in press (Skinner forthcoming) and contain primarily what seem to be dictations and perhaps lecture notes from 1933-1935. Presumably the material will be sourced and dated in the publication, but it seems most likely to pertain to this academic year.

\section{Michaelmas 1934 (M34); Lent 1935 (L35); Easter 1935 (E35)}

According to Redpath (1990: 18) classes met twice per week, Tuesday at 5:00 P.M. and Friday at 5:00 P.M., for two to two and a half hours per meeting, in Wittgenstein's rooms. By Easter term Macdonald's dated notes (1935) show classes being held on Mondays and Wednesdays. Ten to twelve people attended the lectures regularly for the academic year. Students, some more regular than others, included Theodore Redpath, Alice Ambrose, Margaret Macdonald, Abraham Gans, Dave Belmont, Francis Skinner, George Paul, Rush Rhees, R. L. Goodstein, Charles Hardie, A. G. M. Landau, Alister Watson, A.J.T. "John" Wisdom, and Peter Dupré (see Redpath 1990: 19; Ambrose 1967b), but probably not John Cornford (cf. Sloan 1938).

In these lectures Wittgenstein begins to undertake a deeper examination of the notions of following a rule and continuing a sequence. Notes for (M34) are on pages 77-118, (L35) on pages 119-163, and (E35) on pages 164-201 in Ambrose (1979). (See also Macdonald 1935.) Redpath (1990: 105-6) prints a letter he wrote to Wittgenstein raising a question from class, which Wittgenstein then went on to discuss in the next class.

Redpath recalls (1990: 19-20) the atmosphere of these classes:

Wittgenstein's style of lecturing was quite unlike anything I had come across. [. . . I I had not realised [. . .] how [[347]] personal and, in some important sense, 'natural' they would be [...]. Quite often [...] points were sparked off by remarks made by members of the audience at his invitation. For his own train of thought would frequently come to a halt. 
On such occasions he would sometimes sit astride a small upright chair, resting his arms on the back or holding the tops of the uprights, and curse himself roundly in such terms as 'Damn my bloody soul!' [. . .] He seldom had any notes for his lectures_-just occasionally a scrap of paper or an envelope.

In a talk to the Cambridge Moral Sciences Club on May 31, 1935, John Wisdom read a paper on "Moore and Wittgenstein". The minutes for that meeting record (quoted more extensively in Nedo and Ranchetti 1983: 266-67):

People might say that Wittgenstein in his lectures spends an unconscionable time saying nothing definite, that Broad deals out dope, and that Moore pursues a will o' the wisp, but he [Wisdom] has observed that each produces a change in those who go to their lectures which, although it is different in each case, is in each case a change of a kind philosophers have sought.

Wittgenstein also dictated the "Brown Book" to Ambrose and Skinner during this academic year. However, this did not replace his regular lectures.

By the end of the next academic year Wittgenstein's five-year fellowship from Trinity would run out. He became interested in finding work in the Soviet Union as a laborer. He traveled there for two weeks in September but, ironically, the only work he could find was in philosophy: "first a chair in philosophy at Kazan University, and then a teaching post in philosophy at the University of Moscow" (Monk 1990: 351). This was the last thing he wanted to do.

\section{Michaelmas 1935 (M35); Lent 1936 (L36); Easter 1936 (E36)}

Wittgenstein's classes met in his rooms in Whewell's Court on Mondays and Wednesdays this year, commencing on October 11, 1935.

Rhees summarizes topics from (M35) in Rhees 1984a, page 1. Detailed notes of those lectures are given in Macdonald 1935-1936. Notes of (L36), beginning in the middle of February, are in Rhees 1993, pages 290-326. All the lectures from (L36) are included in Macdonald's notes. Notes of (E36) are in Rhees 1993, pages 326367, and Macdonald. There are also notes of these lectures by Smythies and by John Wisdom. Wittgenstein himself made very 
extensive notes, apparently in preparation for these lectures (Wittgenstein 1993e). In both the lecture notes and the preparatory notes, the notion of private experience receives careful scrutiny.

Those attending at this time included Rush Rhees, Yorick Smythies, Margaret Macdonald, Ivor Hickman, Donald Hutchinson, Bruce Brooke Wavell, and Theodore Redpath.

Redpath (1990: 31) recalls the following incident from this year:

There was a student who knew shorthand, and he asked Wittgenstein if he might take down in shorthand what was said and, after Wittgenstein had vetted it, have it circulated to whomever Wittgenstein thought fit. Apparently Wittgenstein agreed to this, and [the student] came a couple of times or so and took the proceedings down in shorthand and then typed them out. Unfortunately, I gather, he [[348]] badly misjudged Wittgenstein's reaction to the typescript. Apparently he thought that Wittgenstein was honest that he would want everything he said to appear in the draft submitted to him, and so the typescript included a good sprinkling of the oaths of which Wittgenstein characteristically delivered himself when he lost the thread of his thought or felt baffled and unable to proceed. [The student] never appeared again, and I heard that Wittgenstein had been wild with anger and submitted the delinquent to a far from gentle dressing down.

Wittgenstein's fellowship ran out at the end of (E36). Wittgenstein's main connection to the Vienna Circle, Moritz Schlick, was murdered June 22, 1936. A few weeks later, on July 11, Wittgenstein's sister Gretl sent him a letter (Wittgenstein 2019: 209) reporting that Friedrich Waismann contacted her wanting to know "whether you might be willing to accept a teaching position in Vienna". Apparently, he declined. Instead, Wittgenstein spent the period from August 1936 to December 1937 largely in Norway. Upon retreating to Norway, Wittgenstein reflected in his diary that

my work (my philosophical work), too, is lacking in seriousness \& love of truth.-In my lectures, for example, I have often cheated by pretending already to understand something while I was still hoping that it would become clear to me (Wittgenstein 2003b, November 23, 1936)

And also his letter to Hänsel (2003a, March 10, 1937): “For countless times I kept from my audience how unclear the matter still was to me then \& acted as if it were already clear, when I was only hoping 
it would yet become clear." On August 16, 1937, Wittgenstein wrote (in code) in his notebook (MS 118: 1v): "In Cambridge I could teach, but not also write."

\section{Lent 1938 (L38); Easter 1938 (E38)}

Wittgenstein seems to have returned to academic life in Cambridge largely because of a desire ultimately to gain British citizenship (Monk 1990: 394-95). It is unclear how quickly this return took place. Redpath (1990: 46-47) recalls twice-a-week classes beginning immediately in (L38). But Wittgenstein's pocket diary notes (McGuinness, letter to the author) only three or four "discussions" in January and February. Monk (p. 401) seems to imply that classes only began in (E38). In any case, the Cambridge University Reporter gives no listing for Wittgenstein's classes during either of these terms. Since Wittgenstein did not want too many people to come, they were apparently not "open" lectures but were for people Wittgenstein had chosen to attend (Redpath 1990: 46). McGuinness reports that the lectures or discussions in these terms were "unpaid."

When Wittgenstein left Cambridge in 1936 he gave up his rooms, so classes now met in James C. Taylor's rooms, K2 in Whewell's Court, and later in rooms of other students such as Rush Rhees. During (L38) Wittgenstein spent time in Dublin as well as Cambridge, but when he was in Cambridge he lived with Skinner at 81 East Road. Redpath recalls classes meeting twice a week for two or more hours a meeting. Classes for (E38) commenced on Monday, April 25, at 5:00 P.M., for lecture, with Fridays for discussion (Wittgenstein's letters to Moore, 1995: 296-97).

The core students were Rush Rhees, Yorick Smythies, James Taylor, Redpath, and Casimir Lewy. Lewy attended all of Wittgenstein's lectures from 1938 through June 1945 (Hacking 1985: x). Redpath (1990: 47) adds to this list: George Paul, Francis Kitto, Alister Watson, and Douglas Gasking. Occasionally Drury attended and then, or perhaps later in the fall, Richard Bosanquet and Margaret Paul (née Ramsey) attended-ten or twelve students in all.

Redpath claims (1990: 47, 76) these lectures were about the foundations of mathematics. Wittgenstein's MS 159, from 1938, 
contains German notes on Gödel's proof and then [[349]] English notes on material related to lectures from (E38) (Wittgenstein 1993a, Appendices A, B, and C). It seems likely, then, that at least the first few lectures of (L38) were on Gödel's proof. Nedo (1993: 37-38) says the announced topic was "Philosophy and Philosophical Foundations of Mathematics." But it seems likely that the lectures were on a variety of topics.

Rhees's notes (Wittgenstein 1993a: 407-411, 419-421, and 423426) all date from (E38). The lectures on Religious Belief (Barrett 1972: 62-72) were apparently part of a larger course of lectures on Belief. These are probably from (L38) or (E38). The aesthetics lectures are claimed, by Barrett (Preface), to date from "the summer of 1938." Rhees (1966) says "The lectures on aesthetics came after the term [(E38)] had ended. For example, in a letter of July 15, 1938, Wittgenstein invites Rhees to "a discussion in Taylor's room (Newmarket Steet) tomorrow (Saturday) at 5pm."

Smythies attended lectures by Wittgenstein from 1938 to 1947, only missing some during the war years. Extensive but largely undated and often indecipherable notes from Smythies (Smythies, no date) are held by Kagoshima International University, Japan. Smythies worked for many years trying to condense and reorganize these notes topically into a book (mainly drawing on the notes from 1938 and occasionally employing notes from other students such as Taylor). Smythies notes for (E38) have been published as (Smythies 2017: 6-84).

Drury, who attended one of the aesthetics lectures, writes (Drury 1984: 141):

During this lecture one of the students was rapidly writing notes. Wittgenstein told him not to do so. "If you write these spontaneous remarks down, someday someone may publish them as my considered opinions. I don't want that done. For I am talking now freely as my ideas come, but all this will need a lot more thought and better expression."

\section{Michaelmas 1938 (M38)}

The Cambridge University Reporter (vol. 68: 1249) had Wittgenstein offering regular announced lectures twice a week from Wisdom's 
rooms. However, in a letter to Moore (Wittgenstein 2008: 286, October 19, 1938), Wittgenstein writes:

I am still not well at all. I am bodily very weak and shaky, and feel incapable of thinking properly about any subject. I cannot therefore start lecturing now, and I don't know whether I shall regain sufficient strength in the next 3 weeks, say, to do so. [...] I wonder whether it had not better be announced in the Reporter that I can't lecture for the present and until further notice.

No notes definitely dating from this term are known. The fact that Malcolm came to Cambridge for this term, but didn't begin attending Wittgenstein's lectures until the following term (Malcolm 1984: 23), suggests that Wittgenstein never ended up giving lectures this term. But, in any case, no cancellation was announced in the Reporter. Rhees (1966) reports: "[Wittgenstein] was not lecturing in the Autumn term of 1938/39”.

A postcard to Moore (Wittgenstein 1995: 302, November 25, 1938) has Wittgenstein spending ten days in Hastings in the middle of term. And in a letter to Hänsel (2003a: 315) dated December 14, 1938, Wittgenstein reports: "For two months I was slightly unwell \& am healthy again now." Redpath also comments (1990: 78) on his poor state during this term. G.E. Moore's diary notes for October 27, 1938: "W. comes for $1 / 2$ hr. + says he has rheumatic pains." [[350]]

\section{Lent 1939 (L39); Easter 1939 (E39)}

Wittgenstein lectured twice a week, Mondays and Wednesdays, at 5:00 P.M., apparently holding no discussion class this term (Moore 1993: 48n. and letter to Moore in Wittgenstein 1995: 310). Class meetings lasted two hours or more. Since Wittgenstein was still living at Skinner's apartment, classes were held in Smythies's rooms in King's College.

Lectures were attended by Norman Malcolm, Douglas Gasking, R. G. Bosanquet, Casimir Lewy, Marya Lutman-Kokoszynska (a visiting scholar from Poland), Rhees, Smythies, Alan Turing (the famous mathematician), Alister Watson, John Wisdom, and G. H. von Wright. (Not Findlay, according to Findlay 1972-1973: 173, and 
not Toulmin, according to Janik and Toulmin 1973: 11.) Present less often were Redpath, Derek Prince, and M. A. Cunningham.

Explaining to von Wright why he did not want casual visitors in his lectures, Wittgenstein (1993d: 459-460: March 9, 1939) wrote:

I am, in my classes, doing my utmost to explain a very difficult matter to the students who have been attending my classes this term. I know that it is quite impossible for any one coming in in the middle, or at the end, of the term to get any idea of what we really are driving at. In fact he must necessarily get wrong ideas [. . . . If I could, as many other people can, prepare my lectures in writing and then read them off in front of the class the presence of new people would not disturb me. But as I'm unable to do this and have to think things out afresh while I'm talking I am very easily disturbed.

Hence, von Wright began attending at the beginning of (E39). The (E39) lectures commenced on April 24.

These are perhaps Wittgenstein's most famous and best documented lectures. They are on the foundations of mathematics. Cora Diamond's edition of students' notes from these lectures (Diamond 1976) is a compilation of notes from R. G. Bosanquet, N. Malcolm, R. Rhees, and Y. Smythies. Rhees's notes (1939) are extant. A bootleg version of Malcolm's notes of these lectures (1954) once had limited circulation. The notes end with the sad lament: "The seed I'm most likely to sow is a certain jargon."

Malcolm (1984: 23) says that Wittgenstein

told me that the only thing that made it possible for him to conduct his lecture classes [extemporaneously] was the fact that he had done and was doing a vast amount of thinking and writing about all the problems under discussion.

Wittgenstein himself made at least some notes specifically in preparation for these lectures (MS 161: 1-32). Malcolm continues (p. 24):

It is hardly correct to speak of these meetings as "lectures", although this is what Wittgenstein called them. For one thing, he always carried on original research in these meetings. [. . . For another thing, the meetings were largely conversation. [. . .] Wittgenstein's personality dominated these meetings. I doubt that anyone in the class failed to be influenced by him in some way. 
Monk (1990: 423) relates, "Exhausted and disgusted by his lectures, he would invariably go to see a 'flick' after them, accompanied by [one of his student] friends from the class. He would always sit in the front of the cinema, where he could be totally [[351]] immersed in the picture. He described the experience [. . .] as 'like a shower bath', washing away his thoughts of the lecture."

Wittgenstein was elected professor of philosophy at Cambridge, succeeding Moore, on February 11, 1939, with the appointment to begin on October 1. In reply to a telegram from Keynes informing him of the decision, Wittgenstein wrote: "I hope to God that you haven't made a mistake. I know, it's up to me to prove that you haven't. Well I hope I'll be a decent prof' (Wittgenstein 2008: 293). In a letter to his old friend Eccles (Wittgenstein 1993g: 11: March 27, 1939), Wittgenstein wrote: "Having got the professorship is very flattering and all that but it might have been very much better for me to have got a job opening and closing crossing gates. I don't get any kick out of my position (except what my vanity and stupidity sometimes gets)." After his election, Wittgenstein told Drury (Drury 1984: 141) "that Broad had said: "To refuse the chair to Wittgenstein would be like refusing Einstein a chair in physics." He obtained his British citizenship on April 14, 1939.

\section{Michaelmas 1939 (M39)}

As summer came to a close, Wittgenstein wrote to Hänsel (2003a: 323: August 26, 1939): "I feel nothing less than capable of teaching philosophy. Well we will see." Then after war broke out in Europe, he wrote to von Wright (1993d: 461: September 13, 1939):

I wish you were here and could help me with my discussion classes. They should start in about 3 weeks; but I can't imagine how I shall be able to lecture. I feel as though, under the present shameful and depressing circumstances, I ought to do anything but discuss philosophical problems, with people who aren't really deeply interested in them anyway.

Nevertheless the Cambridge University Reporter (vol. 70, pp. 93, 453) announced his usual course, to meet Mondays and Thursdays at 5:00 P.M. John N. Findlay says (1984: 20) classes were held Thursday 
evenings in Wittgenstein's rooms in Whewell's Court (which he finally reoccupied this term).

Findlay mentions Malcolm and C. A. Mace as among the others in attendance. Timothy Moore (son of G. E. Moore) also attended Wittgenstein's classes regularly between October 1939 and June 1941. Lewy would have been present as well, and perhaps also Redpath.

Malcolm (1984: 23) and Monk (1990: 415, probably relying on Malcolm) claim that the lectures on foundations of mathematics continued into this term. But J. N. Findlay's account (1972-1973: 173-75; 1984: 20) seems preferable. He says the lectures were on Memory (and dreams). Findlay described the lectures as "extremely incoherent" (p. 175), though he offers a summary of what he found in them (p. 174):

$[\mathrm{H}]$ e was expounding the by now familiar doctrine that memory did not precede but followed the memory language-game, in which people simply felt inclined to talk of events which obviously were not happening when they spoke, and in which other people, to whom they appealed for confirmation, were in some cases strangely willing to do. They too, they said, had [[352]] been there, and had witnessed what the rememberer was describing. The convention arose of speaking of these non-occurrent but confirmable events in the past tense: the reference to the past sprang from the conventional use of the past tense in such linguistic acts of remembering and not vice-versa. Poor old Broad and others who put the reference to the past first were deeply confused: they believed in that great absurdity-pre-linguistic meanings, a language before language. The language of memory resembled the language of dreams, where dream reports are the foundation of dreams and not vice-versa, as Malcolm afterwards spelt out laboriously in his book on Dreams: only no one tried to confirm a dream, whereas other people confirmed one's memories, and looked for evidence that fitted in with them. Findlay [speaking of himself in the third person] regarded the analysis as brilliantly sophistical and said so: Wittgenstein publicly regretted that he could be brought to the water yet not made to drink.

Findlay also recalled that during this term Wittgenstein gave away some of his own books to students, including his copy of Principia Mathematica.

Recently, Malcolm's notes of these lectures, dated from October 13 through December 11, were discovered among Alice Ambrose's 
papers (Add 9938 Box 2, Cambridge University Library). Yorick Smythies's notes for "Lectures on Similarity" (Smythies 2017: 88132) also date from (M39).

In Philosophical Occasions (Wittgenstein 1993: 427-428) Klagge and Nordmann argued that the lectures on freedom of the will probably came from this term. But they now seem more likely to have come from (L41).

Reflecting on his own teaching Wittgenstein wrote (1980/1998: 38/43, January 13, 1940):

A teacher may get good, even astounding, results from his pupils while he is teaching them and yet not be a good teacher; because it may be that, while his pupils are directly under his influence, he raises them to a height which is not natural to them, without fostering their own capacities for work at this level, so that they immediately decline again as soon as the teacher leaves the classroom. Perhaps this is how it is with me; I have sometimes thought so.

\section{Lent 1940 (L40); Easter 1940 (E40); Michaelmas 1940 (M40); Lent 1941 (L41); Easter 1941 (E41)}

Wolfe Mays (1967: 79ff) began attending Wittgenstein's lectures in Lent, 1940, and on for "a year or two". According to Mays, lectures took place in two-hour sessions twice a [[353]] week from 4:00 P.M. to 6:00 P.M. in Wittgenstein's rooms at the top of Whewell's Court in Trinity. The Cambridge University Reporter (vol. 70: 453) has them taking place Mondays and Thursdays at 5:00 P.M.

The number of people present was never more than a dozen. From this period Mays recalls Robert H. Thouless (a psychologist and lecturer in education at Cambridge), Timothy Moore, A. M. Mardiros, Smythies, Stephen Körner, Elizabeth Anscombe, Lewy, and Rose Rand. (However, Anscombe did not in fact come to Cambridge until 1942.) Stephen Toulmin was present at lectures in 1941 (Janik and Toulmin: 11). Perhaps it is from one of these terms that Toulmin's delightful recollection dates (Toulmin 1953: 51): "as Wittgenstein has remarked, "what is or is not a cow is for the public to decide.". Mays recalls (1965):

[Wittgenstein] had certain mannerisms such as holding his chin in his hand, with his eyes half-closed when he had difficulty in explaining his 
ideas, and nodding his head slowly. He disliked pedantic academics and looked much more like a wandering artist than a philosopher.

Smythies notes from (L40), (E40), (M40) and (L41) are published (Smythies 2017: 137-296). Rose Rand (2004: 87-164) has notes in German from (E40), (M40), (L41) and (E41), as well as notes from some of Wittgenstein's “at-home”s during (M40):. Based on Rand's notes from January 20, 1941 (Rand 2004: 128) it seems likely that Wittgenstein's "Lectures on Free Will" (Smythies 1993) date from (L41), and not from (M39) as Klagge and Nordmann had previously conjectured.

Concerning the lectures of this period, Mays recollects: "Wittgenstein's lectures were mainly devoted to questions of meaning, belief, and the foundations of mathematics" (1967: 83). Mays summarizes his impressions of some aspects of these lectures:

His approach to philosophical problems was essentially aesthetic in the widest sense. He had a very strong, almost abnormal imagery, and this came out in the bizarre examples he used to produce in class to illustrate his arguments. For example, he likened his soul to a yellow spot over his shoulder. In the manner of Dean Swift he once tried to draw an analogy between the faces of men and those of animals. You can often, he said, see in one man the resemblance of a horse, in another that of a pig and in another that of a dog. To illustrate the expressionist character of language he suggested that we try swearing at a dog in an affectionate tone of voice, and to bring out the arbitrary nature of naming, he argued that we might christen the piece of chalk he was holding in his hand "Jack." (p. 80)

[Wittgenstein] poked fun at traditional modes of philosophizing, and he used the bed-maker (i.e., female college servant) as a measuring rod when traditional philosophical arguments were raised in class. "What", he would ask, "would my bed-maker say of this kind of abstract talk?” (p. 82)

When he was lecturing on belief he read extracts from James' Principles of Psychology, and discussed them critically. [. . . Wittgenstein often indulged in what I can only call speculative anthropology. This was particularly to be seen in the way he illustrated his arguments by reference to the behavior of hypothetical tribes. [. . .] He might, for example, say, "Imagine how a particular tribe having a different culture could use such an expression to mean something different from what we mean." [. . . In his lectures Wittgenstein made valiant efforts to quote examples to show that psychological data could be externalized. He 
talked a good deal about the criteria for deciding whether a person was in pain or not. Suppose, he said, so and so was on the operating table and surgeons were sticking knives into him; if he showed no signs of reacting, could he therefore be said to be in pain, or was he shamming? In these examples Wittgenstein sometimes tended to regard other people as if they were inanimate objects or automata, as when he said, "Suppose I cut off Mr. X's arm thus", at the same time striking his own left arm with the edge of his right hand. (pp. 83-84)

What has lingered in my mind over the years, as far as Wittgenstein's lectures were concerned, has been the stuffiness of the room in which they were held, the intellectual fog generated, and the puzzled look on the faces of his listeners. The awkward feeling you had [[354]] Wittgenstein was going to pounce on you and ask a question to which you would give what he would consider to be a silly reply. (pp. 84-85)

Wittgenstein's own reflections on the lectures were somewhat more positive. To Malcolm he wrote (Malcolm 1984: 87: March 26, 1940): "My lectures have gone moderately well this term \& I hope they won't be too awful next term" and (pp. 87-88: May 29, 1940):

My lectures didn't go too bad this term, \& last week I had an 'at-home' \& I'm intending to have at-homes regularly now because I have an idea it might steady people a bit if they go on with some sort of decent thinking in spite of the unrest they feel. Of course if people cease to come that'll be just that.

Nedo (1993: 40) quotes the "Lecture-List" from the Cambridge University Reporter: "Prof. Wittgenstein will be at home to his students on Sundays at 5 P.M. in his room in Trinity College."

Redpath (1990: 94) relates that

one day [in Lent term, 1940] I asked him why he never stated any political views or discussed politics in any of his lectures. His reply was interesting. He said he could not do so but that one day he would give a lecture or talk explaining why he could not. He never gave such a lecture or talk while I was still attending his classes.

Redpath stopped going to Wittgenstein's classes in June 1940 (1990: 97).

Mays reports (1967: 81): "Wittgenstein disliked us to take notes during his classes, and he would prevent anyone who was foolhardy enough to try. He did, however, allow Smythies to take notes." 


\section{Michaelmas 1941 (M41); Lent 1942 (L42); Easter 1942 (E42); Michaelmas 1942 (M42); Lent 1943 (L43)}

The (M41) term began with the usual schedule of classes on Mondays and Thursdays at 5:00 P.M. (Cambridge University Reporter, vol. 72: 89). But in November, Wittgenstein began working in London at Guy's Hospital as part of the war effort. During the rest of this whole period (see Cambridge University Reporter) Wittgenstein lectured only on Saturdays, from 5:00 P.M. to 7:00 P.M. Apparently he held class only on alternate Saturdays for at least a while (Henderson 1973: 188).

Many fewer students were at Cambridge during the war. Wittgenstein reported to Rhees (November 11, 1942) that he was lecturing to about ten students. Lewy would have attended regularly, along with Robert Thouless. New faces on the scene included Elizabeth Anscombe, Stephen Körner, and Georg Kreisel. Malcolm (1984: 27) relates that: "During World War II, when he lectured on Saturdays, an American negro soldier was a member of the class. Wittgenstein remarked more than once what a friendly and goodnatured face the man had, and how sorry he was when he ceased to come."

Bouwsma relates (1986: 73): "Miss Anscombe said that during the war he once returned the money Cambridge paid him for lectures: "The lectures were no good, not worth the money." Edmonds and Eidinow (2001: 72) claim that this was during the time when he was only giving lectures on weekends. [[355]]

Wittgenstein's own research was focusing again on the foundations of mathematics, and Rhees (1984b: 224) says Wittgenstein wrote to him in November 1942 that he was lecturing on the foundations of mathematics.

One of Wittgenstein's favorite students was Georg Kreisel, who was in contact with Wittgenstein from 1942 through Wittgenstein's death in 1951. Kreisel had regular conversations with Wittgenstein as well as attending his lectures. Kreisel (1978a: 80) claims:

His lecture-courses [...] were very tense; as were, for that matter, many of his conversations [...] about everyday trivialities. By contrast he was 
extraordinarily relaxed, when analysis of proofs [.. . ] or a bon mot [. . .] was at issue. Still more astounding (for me) was how often he sketched, in a few minutes in the course of Friday afternoon walks, the content of his two-hour seminar the next day, or afterwards, on Saturday evening, supplemented or extended that content. Without exaggeration: what he actually said in the lecture did not really express his thoughts (beforehand and afterwards) very well at all.

And (1978b: 86): "At least in my own experience the style of W[ittgenstein]'s conversations on foundations (not on everyday matters!) was very different from his public performances, which were always tense and often incoherent [. . .]." Kreisel related in a letter (Kreisel 1966):

I think I went to the lectures (once a week on Saturday afternoons) from early 1942 to the end of 1943, and then in the academic year 1946-47. I can't imagine anyone took notes during the wartime lectures because they were a bit theatrical, with lots of pauses and poses, and not suited for note taking.

Kreisel went on to note that John Myhill was an occasional auditor during this period "who came to some lectures and fell asleep in a deck chair."

The respect in which Wittgenstein held Kreisel is indicated by the 1944 anecdote Monk relates (1990: 498, from Rush Rhees) about how Wittgenstein thought Kreisel to be the most able philosopher he had ever met who was also a mathematician-even better than Ramsey. On February 27, 1947, Wittgenstein chaired Kreisel's talk to the Cambridge Moral Sciences Club on "Mathematical Logic".

In April 1943, Wittgenstein moved to Newcastle to join a research medical unit and worked there for nearly a year. While in Newcastle he wrote to Malcolm (1984: 92: September 11, 1943): "I've given up my rooms in College. I'm supposed, of course, to come back there as a professor after the war, but I must say I can't quite imagine how I'll be able to do it. I wonder if I'll ever be able to teach philosophy again regularly. I rather think I shan't be able." In February 1944, having finished this war-related work, he was granted a leave of absence from Cambridge to spend time in Swansea working on his own research. He did not return to Cambridge until October 1944. 
Consequently there were no lectures during the terms from Easter 1943 through Easter 1944.

\section{Michaelmas 1944 (M44); Lent 1945 (L45); Easter 1945 (E45)}

Initial announcements for the Michaelmas term did not include a class from Wittgenstein (Cambridge University Reporter, vol. 75: 87, but then compare p. 331). On returning to Cambridge, Wittgenstein reoccupied his old rooms in Whewell's Court and resumed the customary two two-hour classes each week (Nedo 1993: 43) beginning on Monday, October 16. Thouless and Lewy were again among the attendees, as was Anscombe. Wittgenstein wrote to Rhees (Monk 1990: 476: November 28, 1944): "My class is exceedingly poor. I have so far 6 people, none of whom is really good.” Lectures for (L45) began on Friday, January 19. [[356]]

Monk says (1990: 477): "His lectures dealt with [. . . problems in the philosophy of psychology. [...] He had thought of using as a text William James's Principles of Psychology-primarily to illustrate the conceptual confusions that he was concerned to combat", but (as he wrote to Rhees, November 28, 1944, in Wittgenstein 2008: 371): "you were right; I didn't take James as my text but just talked out of my own head (or through my own hat)." He dealt with material corresponding roughly to sections 189-421 of the Investigations. Anscombe recalls (1981: viii-ix):

I always hated phenomenalism and felt trapped by it. I couldn't see my way out of it but I didn't believe it. It was no good pointing to difficulties about things which Russell found wrong with it, for example. The strength, the central nerve of it remained alive and raged achingly. It was only in Wittgenstein's classes in 1944 that I saw the nerve being extracted, the central thought 'I have got this, and I define "yellow" (say) as this being effectively attacked.-At one point in these classes Wittgenstein was discussing the interpretation of the sign-post, and it burst upon me that the way you go by it is the final interpretation. At another point I came out with 'But I still want to say: Blue is there.' Older hands smiled or laughed but Wittgenstein checked them by taking it seriously, saying 'Let me think what medicine you need. . . . Suppose we had the word "painy" as a word for the property of some surfaces.' The 'medicine' was effective, and the story illustrates Wittgenstein's ability to understand the thought that was offered to him in objection. 
In his notebook in 1944 Wittgenstein wrote: "What I am trying to teach people is the transition from what is not obviously nonsense to what obviously is" (MS 129: 202).

\section{Michaelmas 1945 (M45); Lent 1946 (L46); Easter 1946 (E46)}

Before the beginning of term Wittgenstein pleaded to Malcolm (1984: 98: September 20, 1945): "I hope you'll come to Cambridge before I make up my mind to resign the absurd job of a prof. of philosophy. It is a kind of living death.-I'm going back to it in a fortnight." But he was offering classes according to the usual schedule (Nedo 1993: 44): "In the academic year 1945/46 he holds 2-hour seminars twice weekly on the philosophy of psychology." Classes in (L46) commenced Friday, January 18; classes in (E46) on Friday, April 26.

Stephen Toulmin attended all of Wittgenstein's lectures from Lent 1946 through Easter 1947. He says they were exclusively devoted to material from the Investigations, with special reference to Part II. Toulmin commented on Wittgenstein's style (Janik and Toulmin 1973: 228): "Whereas in the Tractatus he had resorted to myth, he now used parables and fables." And then he goes on to recount two such parables. Since they do not appear in any of the four sets of notes for the following academic year, it seems probable they come from (L46) or (E46). Wasfi A. Hijab (1999) attended all classes from Michaelmas 1945 to Easter 1947. He says they were all devoted to philosophical psychology, but it didn't matter what subject Wittgenstein discussed. What was important was the method he brought to bear on the subject, which was always the same. He always emphasized the importance of the context for understanding things - when we ignore the context, what remains is flawed. In a letter to Rhees (February 2, 1946) Wittgenstein reported: "My lectures aren't too terribly bad but they are pretty poor. I'm talking about problems of Gestalt psychology \& am frightfully unclear myself \& unable to get to the deep aspects of the matter." [[357]]

Hijab (1999) recalls that in the course of a lecture Wittgenstein would often stop for two to three minutes to collect his thoughts. In a two-hour class perhaps fifteen to twenty minutes would be silence. 
Wittgenstein always complained of his difficulty expressing himself. What he gave was more a performance than a lecture. He was investigating philosophy in front of his students, so they could learn how to do philosophy. Though he rarely talked about himself or what he was trying to do in lectures, he did once say that he was trying to discover the "geometry of psychology."

Once Hijab had a friend visit him who wanted to attend one of Wittgenstein's lectures. Wittgenstein refused. He would let anyone attend, but only if staying for the whole term's course. He said: I am like a piano teacher. I am trying to teach a style of thinking, a technique-not a subject matter. If you hear me playing just a bit, you'd think it was awful- just noise, discordant notes. You would think it was a poor performance, but it is not a performance at all. As evidence for this, Denis Paul (2007: 254) recalled a conversation with Erich Heller from this year: "The conversation turned to Wittgenstein, and Erich assured me that it was all a load of nonsense, and he could prove it because he had been to one of his lectures and not understood a word."

Anscombe recalls (1995: 407): "He himself in his classes sometimes said he was as it were giving examples of 'five-finger exercises' in thinking. These were certainly not limited in number like the set a piano teacher might employ, and were not like automatic formulae of investigation." (Cf. Gass 1971: 248: "what you heard was something like a great pianist at practice: not a piece of music, but the very acts which went into making that performance.")

Wittgenstein's letters to Malcolm (1984) offer a sort of running commentary on his classes this year:

My class just now is fairly large, 19 people. Many of them will drop off, of course, \& I wish this process could be accelerated.-Smythies is coming \& a woman who's very good, i.e., more than just intelligent. There is also an Indian (or, at least, he is dark) who seems to be all right; also two American soldiers: one's a dud, the other's nice but I don't think he knows what we're talking about (p. 100: October 30, 1945).

Last term my lectures didn't go too bad, on the whole. At the beginning of the term I thought I wouldn't be able to manage them" ( $p$. 101: December 15, 1945). 
My lectures begin in 3 days. I'll talk a lot of rubbish" (p. 102: January 15, 1946).

I haven't done any decent work for ages apart from my classes. They went all right last term. But now my brain feels burnt out. [...] Tomorrow's my first lecture. Ob Hell! (pp. 102-103: April 25, 1946).

\section{Michaelmas 1946 (M46); Lent 1947 (L47); Easter 1947 (E47)}

Classes met twice a week, Mondays and Fridays-commencing on Friday, October 11, 1946. There were also informal meetings on Saturday afternoons, 5:00 P.M. to 7:00 P.M., on whatever issues happened to come up. Classes met in Wittgenstein's usual rooms in Whewell's Court.

Monk claims (1990: 499) that in this last year at Cambridge Wittgenstein added regular seminars on the philosophy of mathematics to his weekly classes on the philosophy of psychology. And Nedo (1993: 44) claims he gave "two series of seminars, one on the 'Foundations of Mathematics' and one on the 'Philosophy of Psychology." This seems unlikely in light of Malcolm's accounting of Wittgenstein's schedule during this year [[358]] (1984: 46):

Wittgenstein devoted a great deal of time to students that year. There were his two weekly classes of two hours each, his weekly at-home of two hours, a whole afternoon spent with me, another whole afternoon spent with Elizabeth Anscombe and W.A. Hijab, and finally the weekly evening meeting of the Moral Science Club which he usually attended.

Hijab (1999) says the afternoon discussions with him and Anscombe were devoted to philosophy of religion. And he says there were no lectures on the foundations of mathematics. In any case, the Cambridge University Reporter for that academic year (vol. 77: 92, 460, 800) lists Wittgenstein as teaching only one course each term.

Those attending the lectures included Norman Malcolm, Peter Geach, W. A. Hijab, A. C. Jackson, Kanti Shah, Georg Kreisel, Miss H. Martini, J. R. Jones, E. Bruce Hunt, Stephen Toulmin, G. H. von Wright (during E47), G. E. M. Anscombe, Smythies, Gilbert Harris Edwards, Peter Munz, John Vinelott, Stephen Plaister, R.O.C. Winkler, Evangelos Christou and Jani Christou. Jackson reports (Jackson 1966): “There were 31 people present in W's room, which 
held comfortably 12, for his first lecture in 1947; there were 10 present for the last lecture."

The lectures from this academic year are thoroughly documented in Geach (1988), which gives full notes from Geach (pp. 3-116), Shah (pp. 119-232), and Jackson (pp. 235-348). There are also some notes from Malcolm (1984: 41-43) and Edwards (covering classes starting on November 8, 1946, and extending through what is apparently May 16, 1947). The Saturday discussions covered a variety of topics, such as psychical research and aesthetics (Geach: xiii); Malcolm (1984: 45-46) relates a riddle that Wittgenstein told for the purpose of throwing light on the nature of philosophy. (Notes from several Saturday meetings taken by Edwards are given in Wittgenstein 2003: 401-405.)

A preface to the lecture notes taken by Edwards gives a sense of what it was like being in these lectures:

There were a few deck chairs for those who arrived early and the rest of us sat where we could on the floor.

Wittgenstein did not permit note taking, and quite rightly so for his seminars were more akin to [. . . cathartic sessions than the classic pattern of someone who knew a lot transmitting it to we who knew little. He would pose problems such as "What is thinking?" and soon show that attempts to resolve them led only to pseudo-solutions. He would lead himself and all of us into a region of complete puzzlement from which there appeared to be no way out; indeed I well recall him sending us away after one lengthy and exacting session saying "I've completely foxed myself." For this we respected him all the more. The whole of his searching questioning was accompanied with gestures, postures and facial expressions that emphasised his direction; I particularly remember the forehead and eyebrows for he seemed to have the ability to raise one eyebrow almost to the top of his forehead whilst the other remained unmoved; moreover his oft repeated affirmative "Yum", meaning "Yes" went with an indescribable puckering of his most plastic face.

Wittgenstein wrote to von Wright (1993d: 461: February 21, 1947): "My lectures vary a great deal. They are sometimes satisfactory, sometimes unsatisfactory."

In general, Wittgenstein was growing increasingly pessimistic about his role as a teacher. In a notebook that he kept for his work 
this year he wrote (MS 133: 82: November 24, 1946; in [[359]] Wittgenstein 1980/1998: 56/64): "I am showing my pupils sections of an immense landscape, which they cannot possibly find their way around." And also (MS 133: 41: November 19, 1946; in Monk 1990: 507):

My lectures are going well, they will never go better. But what effect do they leave behind? Am I helping anyone? Certainly no more than if I were a great actor playing out tragic roles for them. What they are learning is not worth learning; and the personal impression I make does not serve them with anything. That's true for all of them, with, perhaps, one or two exceptions.

(Cf. also Bouwsma 1986: 9-12, 36; Malcolm 1984: 53, 103 \& 112; and Tranøy 1976: 17.) A. C. Jackson's notes for the year end with this (Geach 1988: 347-48): "The only way to deal with a puzzle is to get someone to see it's not a puzzle. [...] Unless you can show that a puzzle is not a puzzle you are left with what really are puzzles: a puzzle is something with no solution."

Anscombe recalls (1995: 406): "I once heard someone ask Wittgenstein what it all came to, what was so to speak the upshot, of the philosophy he was teaching in the 1940's. He did not answer."

The July 25, 1947, issue of the Cambridge University Reporter (vol. 77, p. 1344) listed Wittgenstein as teaching a class in the following year, but the first October issue no longer listed him. In October 1947, Wittgenstein had resigned his chair effective December 31, 1947. Michaelmas 1947 was a sabbatical for him, which he spent in Cambridge.

\section{Other Lectures}

Wittgenstein gave lectures or participated in discussions in other various circumstances. Only events in which Wittgenstein was designated as a participant are numbered: 


\section{July 13, 1912. "Experiment on Rhythm (Demonstration), by L. Wittgenstein and B. Muscio (Introduced by C.S. Myers)"}

This was a presentation to the British Psychological Society meeting in Cambridge. The meeting included five additional presentations by others (British Psychological Society program, 1912).

Wittgenstein's new friend David Pinsent records in his diary (Monday, May 13, 1912; in von Wright 1990: 3):

At 2.30 I went chez. Wittgenstein and we went on to the Psychological Laboratory, where I had arranged to act as a 'subject' in some experiments he is trying: to ascertain the extent and importance of rhythm in music. Not bad fun.

There are similar reports of experiments six times over the following month. Surprisingly, Pinsent's entry for Saturday, July 13 (the date of the presentation), mentions nothing about it, though it does record that they dined together that evening at the Bull Hotel.

Bernard Muscio (1887-1928) was an undergraduate member of the Cambridge Moral Sciences Club in 1911-1913. He became university demonstrator in experimental psychology [[360]] at Cambridge and later professor of philosophy, University of Sidney. Myers was an experimental psychologist at Cambridge with whom Wittgenstein had some discussions about the relationship between logic and psychology (Wittgenstein 1995: 14, letter to Russell, June 22, 1912).

Moore reported to Hayek:

[Wittgenstein] told me long afterwards, in the Lectures in 1933, that he undertook these experiments, which were on rhythm, in the hope that they would throw some light on questions of Aesthetics, but of course they threw none; but they did, however, establish one point of some interest, namely that, in some circumstances, all the subjects of the experiment heard an accent on certain notes which were in fact not accented by the machine which was being used. (Letter dated March 8, 1953; in Nedo and Ranchetti 1983: 84; also Wittgenstein 2016a: 358359 for Moore's notes on May 26, 1933, of Wittgenstein's description of the project.)

Wittgenstein described the demonstration to Russell (Wittgenstein 1995: 16, July 1, 1912) as "a most absurd paper on rhythms." 
Despite Wittgenstein's dismissal of the paper, in one of his last lectures at Cambridge, on May 16, 1947 (L47), in the course of a discussion of gestalt psychology, he is reported by Gilbert Harris Edwards (1946-1947: 145-146) to have said the following:

Talk of visual organization suggests grouping. Thus if a series of sounds of the same nature follow at equal distances in time, we can hear e.g. every second one as accented. ... Suppose we say we hear the sounds accented - ${ }^{-}$[short/long]. We may ask if this is an auditory matter. Of course it is. There is an auditory experience which will justify it; and we can have such an experience in fact, we can hear the sounds as they are really produced ${ }^{-}$[short/long].

(This discussion took place at p. 101 in Geach's notes: 229 in Shah's notes, and p. 331 in Jackson's notes in Geach 1988, but it is not elaborated in any of those places.)

\section{May 15, 1913. Demonstration "Of an Apparatus for Psychological Investigation of Rhythm"}

The next year Wittgenstein and Muscio gave a demonstration of presumably the same work at the ceremonial opening of the new laboratory for experimental psychology at Cambridge (Cambridge Review, v. 34, no. 859, May 22, 1913: 464).

In the fall of 1913 Wittgenstein was scheduled to give a course of lectures on philosophy to the Working Men's College in London (see Pinsent's diary, pp. 80-81, 83 in von Wright 1990). Members of the Apostles group at Cambridge, such as E. M. Forster, also taught there. Wittgenstein had begun preparations for these lectures when he finally decided to live in Norway instead, and they were never given by him.

Wittgenstein was away from academia more than a dozen years. His interest in philosophical matters was renewed by discussions with Frank Ramsey, from Cambridge, and with some of the members of the Vienna Circle in 1927 and 1928, as well as a talk by the mathematician L.E.J. Brouwer in 1928. Wittgenstein returned to academic life in Cambridge in January 1929 and resumed philosophical research. [[361]] 


\section{July 13, 1929. Lecture "About Generality and Infinity in Mathematics"}

This talk was given to the joint session of the Aristotelian Society and the Mind Association, held at University College, Nottingham, England.

In a letter to Russell (Wittgenstein 1995: 239) requesting his presence, Wittgenstein wrote:

My paper (the one written for the meeting) is 'Some remarks on logical form', but I intend to read something else to them about generality and infinity in mathematics which, I believe, will be greater fun (though it may be all Chinese to them).- I fear that whatever one says to them will either fall flat or arouse irrelevant troubles in their minds and questions $[\ldots]$.

Leavis tells an anecdote about Wittgenstein's exhausted but intense condition the night before this talk (Leavis 1984: 60-61). Upon arrival at the meeting, the Oxford philosopher John Mabbott, mistaking Wittgenstein for some local student, "said to him kindly 'I'm afraid there is a gathering of philosophers going on in here."” Wittgenstein replied, "I too" (Mabbott 1986: 78-79). While Russell did not attend, Gilbert Ryle was among those in attendance, and this led to his acquaintance with Wittgenstein. H.W.B. Joseph was present for the talk and reported (McGuinness, 2016: 210): "[Wittgenstein] reminded me of the Ancient Mariner; he held the audience with his glittering eye, and discoursed excitedly on a discovery about the continuous being only potentially divisible and not actually divided ad infinitum [...]."

There is some uncertainty about whether we have any more evidence about the content of this talk. Venturinha proposes that notes in the Ramsey Archive are preparatory for that lecture (published in Venturinha 2010: 173-181). McGuinness (2016: 210), however, proposes that another piece from the Ramsey Archive (Ramsey 1991: 178-181) might be preparatory for the lecture.

While it may seem that this would have been Wittgenstein's last involvement with the Aristotelian Society, in fact he chaired a meeting of the CMSC that was a joint meeting with the Aristotelian Society on February 1, 1945-featuring a paper by Ewing, "Are Mental Attributes, Attributes of the Body?"-held in Braithwaite's 
rooms in King's College. But when it came to another joint session with the Mind Association, Wittgenstein had had enough. According to Britton (1967: 62):

[Wittgenstein] railed against professional philosophers, mourned the present state of philosophy in England and asked: "What can one man do alone?" When I told him that the next jamboree was to be held at Cambridge in 1947 and that I was to read a paper, he said: "Very well, to me it is just as if you had told me that there will be bubonic plague in Cambridge next summer. I am very glad to know and shall make sure to be in London." (And so he was.)

\section{November 17, 1929. Ethics}

"The Heretics: L. Wittgenstein, Esq., on 'Ethics,' in Falcon Yard, 8.30." (See Calendar section of the Cambridge Review, November 15, 1929 issue, vol. 51, no. 1248: viii). An earlier announcement indicates the Heretics' lectures were held in the Conservative Club Rooms. In the absence of this information, the lecture has come to be titled "A Lecture on Ethics." The lecture was given at the invitation of William Empson (2006: 9). A facsimile reproduction of a page from Wittgenstein's appointment diary (Nedo and Ranchetti 1983: 230) shows the meeting followed one of W. E. Johnson's Sunday afternoon at-homes, which Wittgenstein often attended.

The Heretics Society was a general audience that had no particular interest or training in philosophy. Previous speakers included Bertrand Russell, H. G. Wells, and Virginia Woolf. Several weeks later Wittgenstein discussed the contents of the lecture with members of the Vienna Circle (Waismann 1979: 77, 92-93). (Information on the event itself as well as more on those who attended can be found in McGuinness 2016: 219-220; Black 1987; Klagge 2018; and Klagge forthcoming Ch. 2).

A typescript that was presumably read for this lecture has been published (Wittgenstein 1993b). There is also a handwritten manuscript (MS 189a) that appears to be an earlier draft (Wittgenstein 2014). In the philosophical notebook that Wittgenstein worked in during the week leading up to the lecture (MS 107: 184; Wittgenstein 1993-1996, vol. 2: 111, 113; and 1980/1998: 3/5), he wrote: "What is Good is Divine too. That, 
strangely enough, sums up my ethics. [[362]] Only something supernatural can express the Supernatural." And later: "You cannot lead people to the good; you can only lead them to some place or other; the good lies outside the space of facts."

Apparently out of frustration with the unsatisfying discussions at the Cambridge Moral Sciences Club, Wittgenstein offered to meet informally with students starting in November 1929. The only evidence for this comes from MacIver's diary (McGuinness 2016: 217-222):

Thursday, November 21:

The meeting of the 'Wittgenstein Society' was taking place at eight o'clock [...] in Drury's rooms. [...] The company consisted of Drury, Wittgenstein, Lee, James, Cornforth, Bose and myself, joined afterwards by Shillinglaw, Prizer and a physicist [presumably W.H. Watson]. The discussion was [...] for the most part a duologue between Wittgenstein and Drury [about] how we know the feelings of other persons [...]. Before we broke up, we decided to form a group which should meet regularly, at least next term.

See McGuinness 2016 (225, 235, 242, 244, 248, and 250-251) for discussions that seem to be further meetings of this group, later apparently referred to as the "Toothache Society" (McGuinness 2016: 248).

Wittgenstein's discussions with members of the Vienna Circle continued after his return to Cambridge during his visits to Vienna. Notes from eighteen of these discussions-from December 18, 1929, to July 1, 1932 - were taken by Friedrich Waismann (1979). Since they are closer to private conversations than public discussions, they are not included in this list. But admittedly the distinction is vague.

\section{May 28, 1930. "The Foundations of Mathematics"}

This was a lecture given to the Trinity Mathematical Society at 8:45 P.M. in the Old Combination Room, Trinity College, Cambridge.

The Trinity Mathematical Society was formed in 1919. Founding honorary members included G. H. Hardy and J. E. Littlewood (April 2, 1919). Other early honorary members included Bertrand Russell 
(October 29, 1919) and F. P. Ramsey (November 5, 1924). Over the years, papers were given by Hardy, Littlewood, Born, Eddington, Dirac, Polya, Ramsey, Broad, and Russell, among many others. Francis Skinner, later to become Wittgenstein's friend and student, was secretary for the society beginning in 1931.

Minutes for February 12, 1930, record that "upon the proposal of the Secretary [G. W. Ward] Dr. Ludwig Wittgenstein was declared an honorary member of the Society". His residence at the time was listed as Bishop's Hostal [sic], Trinity College. Minutes of this lecture are given in Wittgenstein 2003 (pp. 373-374). The talk includes his first known critique of the Frege-Russell definition of number.

On June 19, 1930, Wittgenstein met with Waismann and Schlick to discuss (Waismann 1979: 102ff.) what Waismann should say in his upcoming lecture, “The Nature of Mathematics: Wittgenstein's Standpoint", to be delivered in Königsberg in September at the Second Conference on Theory of Knowledge in the Exact Sciences. Although it was not announced in the program, Waismann's wellreceived talk was given along with talks by Carnap on logicism, Heyting on intuitionism, and von Neumann on formalism. While the other lectures were published in 1931, only the first portion of the typescript of Waismann's lecture survives, and was published much later (Waismann 1982; 1986). How close (what we know of) Waismann's lecture in September was to Wittgenstein's own views is a matter of dispute.

In Waismann's addendum (1979: 164f) to the notes of the June meeting, in a discussion of the definition of number, Wittgenstein says: "In Cambridge I explained the matter to my audience in this way [...]." This must refer to the lecture to the Trinity Mathematical Society in May. Thus Wittgenstein's account of the explanation that Waismann goes on to record must be considered, along with the minutes, as part of our evidence about the contents of that lecture. [[363]]

In a letter of July 13, 1938 (Wittgenstein 2008: 279), Wittgenstein apologizes to Rhees for the sudden cancellation of his participation in a philosophical convention - apparently the Fourth International Congress for the Unity of Science meeting at Girton College, 
Cambridge, July 14-19, 1938. Wittgenstein remarks: "It was an awful thought to sit there among logical positivists and the like; even your presence couldn't make up for all the nastiness."

\section{February 19, 1940. "The Descent of Mathematics"}

This lecture was given to the Trinity Mathematical Society (joint meeting with the Adams Society, St. John's College) at 8:30 P.M. in the Old Combination Room, Trinity College, Cambridge. Minutes from this meeting and further details are given in Wittgenstein 2003 (pp. 374-375).

I. J. Good, who was a student in mathematics at Cambridge at this time, attended this lecture and recalls only "the way [Wittgenstein] pointed bony fingers into the middle distance while thinking what to say next." Wittgenstein's student and friend, Georg Kreisel, became president of the society for Michaelmas term, 1943.

In 1941 Wittgenstein agreed to give the annual 'Philosophical Lecture' to the British Academy in 1942. He prepared notes for the lecture (published as Wittgenstein 1993f) but ultimately decided not to give the lecture. In a letter to the Academy dated October 20, 1941, he writes (Skinner, forthcoming, Appendix C):

I very much regret to inform you that I shall be unable to deliver The Philosophical Lecture of the British Academy which I promised to deliver next March. I am leaving the University to take up some war work which will leave me no time to write the lecture. [...] I could, if you think that this is all right, deliver a purely oral lecture + should, of course, in this case not expect to be paid for it.

His friend Francis Skinner had died suddenly on October 11, 1941, and Wittgenstein began working at Guy's Hospital in November. Wittgenstein did not leave the University, but taught a much-reduced schedule. C. D. Broad gave the lecture in 1942.

In the 1940s, when he was free from other duties, Wittgenstein spent a good deal of his time in Swansea, Wales, with his friend Rush Rhees. Rhees recalls (1984b: 201) Wittgenstein's participation in the discussion of a paper by classics professor Benjamin Farrington on "Causal Laws and History" at the College Philosophical Society in Swansea in 1943, where Wittgenstein commented that: 
when there is a change in the conditions in which people live, we may call it progress because it opens up new opportunities. But in the course of this change, opportunities which were there before may be lost. In one way it was progress, in another it was decline. A historical change may be progress and also be ruin. There is no method of weighing one against the other to justify [.. .] speaking of "progress on the whole".

Farrington said that even "with all the ugly sides of our civilization, I am sure I would rather live as we do now than have to live as the caveman did". Wittgenstein replied: "Yes of course you would. But would the caveman?"

While Wittgenstein was employed in medical research at Newcastle during the 1943-1944 academic year, he attended a Friday evening talk by Dorothy Emmet at the British [now Royal] Institute of Philosophy. In the discussion Wittgenstein ignored her paper and:

for some reason quite unconnected to the paper we got unto what nowadays are called 'out of body experiences', where consciousness seems to be detached and floating free. Freda Herbert, who, as a medical biochemist knew about anaesthetics, told us that in the case of some anaesthetics the higher centres come back before the lower ones, so that one can be conscious without any physical sensation. This interested Wittgenstein; he said that he remembered coming to after an operation and 'My soul was a black ghost in the corner of the room, and it gradually came nearer and took possession of my body.' (Flowers and Ground 2016, vol. 2: 732-733)

Wittgenstein was involved at least once in the discussions of a student literary society called "The Contemporary." According to J. P. Stern (1989: 11ff.), the society had about twelve membersstudents who studied German unapologetically, feeling that the war was behind them. "We were emphatically anti-war and against the general spirit of the time." Meetings took place in the college rooms of members.

On a "cold, wet November evening in 1944" they were discussing the concepts of honor, valor, loyalty, and justice in the Iliad. A confusing argument went back and forth [[364]] over how they relate to contemporary notions, and words like "decadent relativism" were used. 
Stern describes his first impression of Wittgenstein at this meeting:

The man on the bench at the bay window had kept his raincoat on; the woolen cap on his knees and the firm shoes reminded one of a farmer from the North. Supporting his chin were the hands that held the handle of his walking stick, made of ash-wood; the posture of the rather slight, forward-leaning body conveyed the impression of concentration and mental energy, and at the same time that of impatience. With his first words he claimed and received the attention of everyone. The voice was not loud but full-sounding, I found it immediately engaging; the light accent was Southern German or Austrian [. . .], and in this warm, melodious voice rested a kind of authority I have never encountered since. The name that was mentioned by the chairman when presenting the speaker was unknown to me.

Stern then recounts Wittgenstein's remarks:

Our terminology (so he began the argument) is neither identical to that of Homer, but also not entirely different from it. Surely the language of Homer is doubly strange to us, in terms of time and place- the analogy of a foreign language may well be literally correct, and yet in a certain sense it isn't correct after all. We understand what Homer means when he speaks of the heroism of someone like Achilles or of the mourning of someone like Priam—not because these concern 'eternal values' or the 'eternally human' (as one of the speakers had maintained) but because we are connected to Homer's world somewhat as by a rope. A rope, however, is not of one piece but consists of many interwoven, partially overlapping short strands of hemp of which none reaches from one end to the other- even the famous 'central thread [rote Faden]' the 'red strand' with which the Royal Navy marks its property-is spun from short pieces. The strength of the rope-our confidence that we really understand those terms-depends on the reaching-over and cutting-across of the particular, successively following usages of words; they produce what we call a tradition. And what is true for words like 'virtue' and 'heroism' (the speaker concluded), holds also for what people at different times called 'history,' 'philosophy,' and the like.

“And truth?" Stern asked.

Why should the grammar of the word 'truth' be composed differently, he answered, than that of the just-mentioned words? 
Stern calls this meeting the first of a long series of arguments and encounters with Wittgenstein over the next two years. Whether Wittgenstein attended any further meetings of the society is unclear.

\section{April 10 and 17, 1946. "Motives and Causes"}

Two Wednesday discussions with a small group of students at University College, Swansea, in Wales. Karl Britton recalls (1954: 712):

he did not get where he wanted: but I noticed his "wider" and more receptive attitude: but also a tendency (not altogether new) to be very [[365]] hard on his friends and kindly to the uninitiated. When he was going I persuaded him to come again next week, although Rhees would be away; and my students said: "We have never seen a man thinking before."

\section{May 14, 1947. Opening the Discussion of a Paper Given by Oscar Wood on Descartes's “Cogito, Ergo Sum”}

Wittgenstein accepted an invitation to speak to the Jowett Society meeting at Magdalen College, Oxford. He was to open the discussion of a paper by Oscar Wood, the undergraduate secretary of the society.

In her diary, Mary Warnock (Monk 1990: 496) notes that the room was packed-in attendance was "practically every philosopher" Warnock had ever seen, notably "Gilbert Ryle, J. O. Urmson, Isaiah Berlin, and Joseph Pritchard". Warnock continues:

In his reply to Wood's paper Wittgenstein ignored altogether the question of whether Descartes' argument was valid, and concentrated instead on bringing his own philosophical method to bear on the problem raised $[\ldots]$.

Wittgenstein: If a man says to me, looking at the sky, 'I think it will rain, therefore I exist,' I do not understand him.

Pritchard: That's all very fine; what we want to know is: is the cogito valid or not?

Pritchard (described by Mary Warnock in her diary as "extremely old and deaf with a terrible cough. Totally tactless") several times interrupted Wittgenstein in an effort to get him to address the 
question of whether Descartes' cogito was a valid inference or not. And every time he did so, Wittgenstein avoided the question, implying that it was unimportant. What Descartes was concerned with, Pritchard retorted, was far more important than any problem that Wittgenstein had discussed that evening. He then, in Mary Warnock's words, "shuffled out in disgust". He died about a week later. (See also Warnock 2016: 752-753.)

Isaiah Berlin recalled the event, in a letter to the speaker, Oscar Wood (Berlin 2015: 308-309):

I remember that after your paper he began talking about psychological verbs, and said something like 'I can say when the bell rang, but if I say "At that time Mr Wood began to dress very well", I cannot, in answer to the question "Precisely when did this happen?", give the hour.' Then Pri[t]chard did indeed get up and said, 'I thought we were discussing Descartes' cogito ergo sum — does Professor Wittgenstein'—both the 'W' and the 'st' were pronounced in an English and not a German fashion'believe that this is a valid inference?' To which Wittgenstein replied, 'I did not come here to discuss Descartes: honest, I didn't', and then began talking about psychological verbs again, and said, 'I can say "I have started believing, doubting, wondering" but I cannot say "I started knowing": this does not demonstrate anything, but it is an important pointer.' At which Pri[t]chard rose again and said, 'Would Professor Wittgenstein mind saying whether cogito ergo sum, in his opinion, is true or false: yes or no?' It was at this point that I think [Thomas] Weldon looked very cross, indeed angry, and said, 'We really must ask Professor Wittgenstein to continue, and not interrupt in this fashion.' At which point Pri[t]chard got up, looking furious, and stumped out of the room—and I think he died a few weeks later.

Antony Flew (in a paper of March 25, 2000, reported by Denis Paul) recalls Wittgenstein as follows: "[When Pritchard pressed him, Wittgenstein] replied 'Cogito ergo sum. That's a very peculiar sentence', pointing to his own head at the words 'cogito' and 'sum'."

Philippa Foot (2001: 1) adds that during the discussion, "Wittgenstein interrupted a speaker who had realized that he was about to say something that, although it seemed compelling, was clearly ridiculous, and was trying [...] to say something sensible instead. 'No,' said Wittgenstein. 'Say what you want to say. Be crude and then we shall get on." Foot (letter to the author) recalls that Pritchard crossly asked why Wittgenstein would keep "talking about 
babies" (presumably he had been talking about what a child would have to know when it came to understand some expression).

In addition to the May $14^{\text {th }}$ meeting, Foot says there was a second discussion the next day. Berlin's letter continues (p. 309): “[... ] I also remember Wittgenstein saying, 'I am on an ascending curve and I should like to go on talking'; and [John] Holloway said, 'My name is Mr Holloway and I have a room in All Souls', and offered it for the next day." Warnock recalls (Warnock 2016: 754): "Wittgenstein [...] talked about the difference between 'psychological' verbs describing experiences and others, and then launched into the longest and most coherent discourse yet on thinking of the different languages we use and have ready to hand like tools in a box."

In the following years Wittgenstein referred to Oxford as "a philosophical desert" and "the influenza area" (Malcolm 1984: 79).

Wittgenstein taught his final classes at Cambridge in June 1947, and officially retired at the end of the calendar year. However, a later student at Cambridge, Euan Hill, recalls Wittgenstein's on-going contact with students there (Hill letter to the author, August 10, 2013):

The reason you won't have seen my name is that I've spent my life outside academia. Wittgenstein once said that I had been successfully cured of Philosophy! That was in my last year at Cambridge, shortly before he died. It's a typical Wittgenstein cryptic remark. I was at Trinity College, Cambridge from 1948-1952 [1951??]. He did not give formal lectures then and was no longer the Professor of course. He selected certain students through the intermediary of John Wisdom, who was my tutor, for periodic face-to-face interviews. In my year in the whole of Cambridge there were only 6 students doing the Moral Sciences Tripos. At these interviews he planted what we called time-bombs. It took a year for you to feel the effect.

Nothing more is known of these meetings.

In July and August 1949, during a visit to the United States (fully recounted in Pinch and Swedberg 2016), Wittgenstein had several informal discussions with faculty members at Cornell University, including Bouwsma, Malcolm, Max Black, Stuart Brown, Willis 
Doney, and Gregory Vlastos. (Apparently he pointedly avoided meeting with Alice Ambrose, who was also in Cornell at the time.) Some of the issues are [[366]] recounted by Bouwsma (1986: 3-42) and Malcolm (1984: 70), including Descartes's cogito, ethics, free will, religion, meaning, knowledge, and Frege's philosophy. (See also Nelson 1966.)

While Wittgenstein was at Cornell, Gregory Vlastos gave a paper to the Graduate Philosophy Club in Morrell Hall on the Kantian question "Does Ought imply Can?" to which he answered in the affirmative. Wittgenstein participated in the discussion (recounted from multiple sources in Pinch \& Swedberg: 979-984). Harry Frankfurt was a graduate student at Cornell at the time and recounted the event as follows (Frankfurt 2011: 94):

Wittgenstein made a great deal out of how difficult it is to arrive at a really clear understanding of what is meant by the word "can." [...] although I found the substance of the discussion forgettable, the man Wittgenstein himself was quite memorably entrancing. Even apart from the subtlety and philosophical intelligence he displayed during the discussion, he shone somehow with a very remarkable, nearly incandescent, inner light - a light of single-minded and uncannily concentrated and pure dedication to a search for clarity and for truth. At least to me, it seemed that Wittgenstein was pervasively, throughout his being-almost supernaturally-dedicated to these ideals, with an unequivocal and surpassingly wholehearted commitment and integrity. I have encountered nothing like that marvelous intellectual saintliness $[\ldots]$.

Another graduate student, William Kennick, described the substance of Wittgenstein's response (Pinch \& Swedberg 2001: 983):

'A nurse says to me, "swallow this tube, please." ... "I can't." "But you really ought to, you know." "Yes, but I can't." 'That was it. Does 'ought' imply 'can'? Is 'I ought to, but I can't' contradictory? No.

\section{September 1949. Two Talks on the Problems of Knowledge and Certainty}

While visiting Norman Malcolm, after retirement from Cambridge, Wittgenstein gave two talks to philosophy graduate students at Cornell University, Ithaca, New York, on two consecutive evenings: 
"once talking about verification, once about knowledge" (Malcolm 1984: 70; cf. also recollections in Pinch \& Swedberg, 2016: 984-986). One of the students, William Gass, recalls (1971: 96):

He met with us, the graduate students there in philosophy, for two twohour sessions. Monologues they were really, on the problems of knowledge and certainty, but since it was his habit merely to appearto appear and to await a question-it was we who had to supply the topic, and for that delicate mission one of us was carefully briefed. G. E. Moore had once asked [...] how do I know that this is a hand? And it was thought that the opening question might properly, safely, touch on that. Not all of us were primed, though, and before anyone realized what was happening a strange, unforeseen and uncalculated question had rolled down the table toward the master. Aristotle? Had it to do with Aristotle? And Wittgenstein's face fell like a crumpled wad of paper into his palms. Silence. Aristotle. We were lost. He would leave. In a moment he would rise and shuffle out, pained and affronted. Then Paul Ziff put his question—ours-for it was he who had been the student appointed; and after a terrible empty moment, Wittgenstein's head came up, and he began.

I thought, at the time, I'd undergone a conversion, but what I'd received, I realize now, was a philosophy shown, not a philosophy argued. Wittgenstein had uttered what he felt could be uttered (and it was very important), but what he had displayed could only be felt and seen - a method, and the moral and esthetic passion of a mind in love.

Drury recalls (1984: 158) that in the autumn of 1948, in answer to his question whether he had ever read anything of Aristotle's, Wittgenstein answered: "Here I am, a one-time professor of philosophy who has never read a word of Aristotle!"

\section{Late Winter, 1950. "What One Sees When Looking through a Microscope"}

Wittgenstein attended a meeting with the Kraft Circle in Vienna, a student version of the old Vienna Circle. Meetings were held twice a month at the Kolingasse, the headquarters of the Austrian College Society.

Wittgenstein was invited to a meeting, at Anscombe's suggestion, by Paul Feyerabend after Anscombe had been unsuccessful 
explaining Wittgenstein's ideas to the circle. He eventually agreed to come. According to Feyerabend's recollections:

I started summarizing what we had been doing and made some suggestions of my own. Wittgenstein was over an hour late. "His face looks like a dried apple", I thought, and continued talking. Wittgenstein sat down, listened for a few minutes, and then interrupted: "Halt, so [[367]] geht das nicht!" (“Stop, that's not the way it is!") He discussed in detail what one sees when looking through a microscope- these are the matters that count, he seemed to say, not abstract considerations about the relation of "basic statements" to "theories." I remember the precise way in which he pronounced the word Mikroskopp. There were interruptions, impudent questions. Wittgenstein was not disturbed. He obviously preferred our disrespectful attitude to the fawning admiration he encountered elsewhere. [...] Wittgenstein, I heard, had enjoyed himself. (Feyerabend 1995: 76)

In the spring of 1950 Wittgenstein received an invitation from Oxford University to deliver the annual series of six John Locke lectures for 1950 (for $f^{200)}$ ). Bouwsma (1986: 56-57) notes that Wittgenstein

had been approached by Ryle to give the John Locke lectures, but there would have been an audience of two hundred and no discussion. $\mathrm{He}$ wouldn't do it. People would hear and make something cheap of what he said. He might do something for a group of friends.

(Compare his letter to Malcolm, 1984: 126: April 5, 1950.) The 1950 lectures were, as it happened, given by his American friend O. K. Bouwsma.

Note: I began gathering information for this paper in 1994. Unfortunately, by then many people who might have had helpful information about Wittgenstein's lectures had already died. For others, so much time had passed that useful details were hard to recollect. I would like to thank the following for their assistance: William Boos; Gabriel Citron; Rowan Cruft of the Cambridge Moral Sciences Club; John Dawson of the University of Cambridge Computing Centre; Cora Diamond; Christian Erbacher; Philippa Foot; Arthur Gibson; I. J. Good; Wasfi Hijab and his daughter Nadia Hijab; Euan Hill; Alice Ambrose Lazerowitz; Brian McGuinness; 
Volker Munz; Alfred Nordmann; Bernt Österman; Trevor Pinch; Josef Rothhaupt; Theodore Redpath; Ross Scimeca of the Hoose Library of Philosophy, University of Southern California; Cedrick B. A. Smith; Ian Smith of Bernard Quaritch, Ltd., London; Jonathan Smith and the staff of Wren Library, Trinity College, Cambridge; David Stern; David Thouless; Georg Henrik von Wright; and Sam Webster and Alan Bain of the Trinity Mathematical Society. I shall be grateful for any additional information and corrections that others studying Wittgenstein's lectures might wish to suggest.

\section{References}

References to items in Wittgenstein's Nachlass use the established numbering. All items can be found in facsimile in Wittgenstein 2015-, and their transcriptions in Wittgenstein 2016-.

Åmås, K. O., and R. Larsen, 1994. "Ludwig Wittgenstein in Norway, 19131950". In Wittgenstein and Norway, eds. K. Johannessen, R. Larsen, and K. Åmås. Oslo: Solum Forlag. Reprinted in Flowers, ed. 1999, vol. 1. Ambrose, A., 1967a. Letter to O. K. Bouwsma. In O. K. Bouwsma, "The Blue Book". In Wittgenstein: The Man and His Philosophy, ed. K. T. Fann. New York: Dell. [This letter was written between 1958 and 1961.] Ambrose, A., 1967b. Letter to S. Morris Engel, November 21, Hoose Library of Philosophy, University of Southern California.

Ambrose, A., 1972. "Ludwig Wittgenstein: A Portrait". In Ludwig Wittgenstein: Philosophy and Language, ed. A. Ambrose and M. Lazerowitz. New York: Humanities. Reprinted in Flowers, ed. 1999, vol. 2.

Ambrose, A., 1984. "The Yellow Book Notes in Relation to The Blue Book". In Essays on the Unknown Wittgenstein, ed. M. Lazerowitz and A. Ambrose. Buffalo, N.Y.: Prometheus.

Ambrose, A., 1989. "Moore and Wittgenstein as Teachers". Teaching Philosophy 12: 107-113.

Ambrose, A., ed. 1979. Wittgenstein's Lectures: Cambridge, 1932-1935. Totowa, N.J.: Rowman \& Littlefield.

Anscombe, G. E. M., 1981. Introduction to Metaphysics and the Philosophy of Mind. Vol. 2 of Collected Philosophical Papers of G. E. M. Anscombe.

Minneapolis: University of Minnesota Press. 
Anscombe, G. E. M., 1995. "Cambridge Philosophers II: Ludwig Wittgenstein”. Philosophy 70: 395-407.

Barrett, C., ed. 1972. L. Wittgenstein: Lectures and Conversations on Aesthetics, Psychology, and Religious Belief. Berkeley: University of California Press.

Berlin, I., 2015. Affirming: Letters, 1975-1997, ed. H. Hardy and M. Pottle. London: Chatto \& Windus.

Black, M., 1987. Transcription of an Interview by S.O. Rosenbaum. Cornell University Library Special Collections.

Bose, S. K., 1978. Letter to John King, April 5. Wren Library, Trinity College, Cambridge.

Bouwsma, O. K., 1986. Wittgenstein: Conversations, 1949-1951, eds. J. L. Craft and R. E. Hustwit. Indianapolis: Hackett. Excerpts reprinted in Flowers, ed. 1999, vol. 4.

Braithwaite, R., 1928. "Time and Change", Aristotelian Society Supplementary Volume, vol. 8: 162-174.

Braithwaite, R., 1933. "Philosophy". In University Studies, ed. H. Wright. London: Ivor Nicholson \& Watson, 1-32.

British Psychological Society Program. 1912. British Journal of Psychology 5, no. 3: 356.

Britton, K., 1954. "Recollections of L. Wittgenstein". Cambridge Journal 7, 709-715.

Britton, K., 1966. Letter to Sister Mary Elwyn McHale. Cornell University Library Special Collections. July 22, 1966.

Britton, K., 1967. "Portrait of a Philosopher". In Wittgenstein: The Man and His Philosophy, ed. K. T. Fann. New York: Dell. Reprinted in Flowers, ed. 1999, vol. 2.

Cambridge Moral Sciences Club minutes. Cambridge University Library. Cambridge University Reporter, vols. 60 (1929-1930) through 78 (1947-1948).

Citron, G., ed. 2015. "A Discussion Between Wittgenstein and Moore on Certainty (1939): From the Notes of Norman Malcolm". Mind, Vol. 124, no. 493, January 2015, 73-84.

Cornforth, M., 1939. "Recollections of Cambridge Contemporaries". In David Guest: A Scientist Fights for Freedom (1911-1938), A Memoir, ed. C. H. Guest. London: Lawrence \& Wishnet Ltd.

Diamond, C., ed. 1976. Wittgenstein's Lectures on the Foundations of Mathematics: Cambridge, 1939. Ithaca, N.Y.: Cornell University Press.

Drury, M. O'C. 1984. "Conversations with Wittgenstein". In Recollections of Wittgenstein, ed. R. Rhees. Rev. ed. New York: Oxford University Press. Reprinted in Flowers, ed. 1999, vol. 3.

Edmonds, D., and J. Eidinow. 2001. Wittgenstein's Poker: The Story of a TenMinute Argument between Two Great Philosophers. New York: Ecco.

Edwards, G. H., 1946-1947. “Wittgenstein's Lectures”. Wren Library, Trinity College, Cambridge. 
Empson, W., 2006. Selected Letters of William Empson. Ed. J. Haffenden.

Oxford: Oxford University Press.

Erbacher, C., 2016. "Wittgenstein and His Literary Executors". Journal for the History of Analytic Philosophy, vol. 4. no. 3.

Ewing, A. C., 1948. "Is Metaphysics Impossible?" Analysis 8, no. 3 (January), 33-38.

Feyerabend, P., 1995. Killing Time: The Autobiography of Paul Feyerabend. Chicago: University of Chicago Press.

Findlay, J. N., 1972-1973. "My Encounters with Wittgenstein”. Philosophical Forum 4, no. 2 (Winter): 167-185. Reprinted in Flowers, ed. 1999, vol. 3.

Findlay, J. N., 1984. "Introductory". In Wittgenstein: A Critique. Boston: Routledge Kegan Paul.

Flowers, F. A., ed. 1999. Portraits of Wittgenstein. Vols. 1-4. Bristol, U.K.: Thoemmes.

Flowers, F.A., and I. Ground, eds. 2016. Portraits of Wittgenstein. Vols 1-2. Expanded edition. London: Bloomsbury Press.

Foot, P., 2001. Natural Goodness. New York: Oxford University Press.

Frankfurt, H., 2011. "Reflections of My Career in Philosophy". In Proceedings and Addresses of the American Philosophical Association. Vol. 85, Issue 2, November 2011.

Gasking, D.A.T., 1966. Letter to Sister Mary Elwyn McHale. Cornell University Library Special Collections. August 12, 1966.

Gasking, D. A. T., and A. C. Jackson, 1967. "Wittgenstein as a Teacher". In Ludwig Wittgenstein: The Man and His Philosophy, ed. K. T. Fann. New York: Dell. Reprinted in Flowers, ed. 1999, vol. 4.

Gass, W., 1971. "A Memory of a Master". In Fiction and the Figures of Life, 247-52. Boston: Nonpareil. Reprinted in Flowers, ed. 1999, vol. 4.

Geach, P. T., ed. 1988. Wittgenstein's Lectures on Philosophical Psychology: 194647. Chicago: University of Chicago Press.

Geach, P. T., 1998. Letter to the Times Literary Supplement, February 13: 17. Reprinted in Flowers, ed. 1999, vol. 3.

Gibson, A., 2010. “The Wittgenstein Archive of Francis Skinner". In Wittgenstein After His Nachlass, ed. Nuno Venturinha. New York: Palgrave-Macmillan.

Goodstein, R. L., 1966. Letter to Sister Mary Elwyn McHale. Cornell University Library Special Collections. September 13, 1966.

Goodstein, R. L., 1972. "Wittgenstein's Philosophy of Mathematics". In Ludwig Wittgenstein: Philosophy and Language, ed. A. Ambrose and M. Lazerowitz. New York: Humanities.

Grattan-Guinness, I., 1992. "Russell and Karl Popper”. Russell 12, no. 1 (Summer): 6-18. 
Hacking, I., ed. 1985. "Biographical Note". In Exercises in Analysis: Essays by Students of Casimir Lewy. New York: Cambridge University Press.

Hardy, G. H., 1992. A Mathematician's Apology. New York: Cambridge University Press.

Henderson, J. R., 1973. “Ludwig Wittgenstein and Guy's Hospital”. Guy's Hospital Reports 122: 185-193. Reprinted in Flowers, ed. 1999, vol. 3.

Hijab, W., 1999. "Wittgenstein and His Philosophy". Two talks given at the Twenty-Second International Wittgenstein Symposium Kirchberg am Wechsel, Austria, August.

Ignatieff, M., 1998. Isaiah Berlin: A Life. London: Chatto \& Windus.

Inman, J., 1931. Copy of notes of lectures by Wittgenstein, Lent and Easter terms, 1931. Wren Library, Trinity College, Cambridge.

Jackson, A.C., 1966. Letter to Sister Mary Elwyn McHale. In Cornell University Library Special Collections. August 16, 1966.

Janik, A., and S. Toulmin, 1973. Wittgenstein's Vienna. New York: Simon \& Schuster.

King, J. E., n.d. "Additional Facts and Memories of Wittgenstein, His Lectures and Conversations". Wren Library, Trinity College, Cambridge.

King, J. E., 1930-1931. Notes of lectures by Wittgenstein, academic year 1930-1931. Wren Library, Trinity College, Cambridge.

King, J. E., 1931-1932. Notes of Lectures by Wittgenstein, academic year 1931-1932. Wren Library, Trinity College, Cambridge.

King, J. E., 1984. "Recollections of Wittgenstein”. In Recollections of Wittgenstein, ed. R. Rhees. New York: Oxford University Press.

Klagge, J. C. 2018. "Wittgenstein and His Students: 1929-1933". In Wittgenstein in the 1930s: Between the Tractatus and the Investigations, ed. D. Stern. New York: Cambridge University Press.

Klagge, J. C., 2018a. "Review of Wittgenstein: Lectures, Cambridge, 1930-1933, From the Notes of G. E. Moore Edited by David G. Stern, Brian Rogers, and Gabriel Citron, Cambridge University Press, 2016, and Wittgenstein's Whewell's Court Lectures: Cambridge, 1938-1941, From the Notes by Yorick Smythies Edited by Volker Munz and Bernhard Ritter, Wiley Blackwell, 2017". Philosophy: Journal of the Royal Institute of Philosophy, Vol. 93, No. 365, July 2018, 471-475.

Klagge, J. C., forthcoming. Wittgenstein's Artillery: Philosophy as Poetry, Draft. Kreisel, G., 1978a. "Zu Wittgensteins Gesprächen und Vorlesungen über die Grundlagen der Mathematik". In Wittgenstein and His Impact on Contemporary Thought: Proceedings of the Second International Wittgenstein Symposium, 29th August to 4th September 1977, ed. E. Leinfellner et al. Vienna: Hölder-Pichler-Tempsky, 79-81. 
Kreisel, G., 1978b. Review of Wittgenstein's Lectures on the Foundations of Mathematics. Bulletin of the American Mathematical Society 84, no. 1 (January), 79-90.

Leavis, F. R., 1984. "Memories of Wittgenstein". In Recollections of Wittgenstein, ed. R. Rhees. New York: Oxford University Press. Reprinted in Flowers, ed. 1999, vol. 2.

Lee, D., 1930-1931. Notes of lectures by Wittgenstein, Lent 1930-Easter 1931. Wren Library, Trinity College, Cambridge.

Lee, D., 1979. “Wittgenstein: 1929-1931”. Philosophy 54: 211-220. Reprinted in Flowers, ed. 1999, vol. 2.

Lee, D., ed. 1980. Wittgenstein's Lectures: Cambridge, 1930-1932. Totowa, N.J.: Rowman \& Littlefield.

Lewy, C., 1976. Preface to Meaning and Modality. New York: Cambridge University Press.

Mabbott, J., 1986. Oxford Memories. Oxford: Thornton's. Excerpt reprinted in Flowers, ed. 1999, vol. 2.

Macdonald, M., 1935. TS of notes of last eight lectures of Easter term, 1935. Hoose Library of Philosophy, University of Southern California.

Macdonald, M., 1935-36. "Personal Experience". Notes from Wittgenstein's lectures, 1935-1936. Portions supposedly forthcoming in J. Conant and C. Diamond, eds. Ludwig Wittgenstein: Lectures on Personal Experience, Cambridge, Michaelmas Term, 1935. Cambridge, MA: Harvard University Press. (Once announced, but apparently on hold.)

Malcolm, N., 1954. Math Notes by [sic] L. Wittgenstein. San Francisco, bootleg printing of notes by Malcolm of Wittgenstein's 1939 lectures. Copy in UCLA Library Special Collections.

Malcolm, N., 1959. Dreaming. New York: Humanities.

Malcolm, N., 1984. Ludwig Wittgenstein: A Memoir. ${ }^{\text {nd }}$ ed. New York: Oxford University Press. Reprinted in Flowers, ed. 1999, vol. 3.

Mays, W., 1965. Letter to Sister Mary Elwyn McHale. Cornell University Library Special Collections. July 6, 1965.

Mays, W., 1967. "Recollections of Wittgenstein". In Ludwig Wittgenstein: The Man and His Philosophy. New York: Dell. Reprinted in Flowers, ed. 1999, vol. 3.

McGuinness, B., 1988. Wittgenstein: A Life, Young Ludwig (1889-1921). Berkeley: University of California Press.

McGuinness, B., 2016. “Arthur MacIver's Diary: Cambridge (October 1929_ March 1930)". In Wittgenstein-Studien, vol. 7: 201-256.

Monk, R., 1990. Ludwig Wittgenstein: The Duty of Genius. New York: Free Press. Moore, G. E., 1929-1939. “Extracts on Wittgenstein from Diary 1929-39”. Add 8330 in Wren Library, Trinity College, Cambridge.

Moore, G. E., 1993. “Wittgenstein's Lectures in 1930-33”. In Wittgenstein 1993. Excerpts reprinted in Flowers, ed. 1999, vol. 2. 
Moore, G. E., 1993a. "Being Certain that One is in Pain". In G. E. Moore: Selected Writings, ed. T. Baldwin. New York: Routledge: 197-206.

Moore, G. E., 1993b. "Moore's Paradox". In G. E. Moore: Selected Writings, ed. T. Baldwin. New York: Routledge: 207-212.

Munz, P., 1998. Letter to the Times Literary Supplement, March 27: 17. Reprinted in Flowers, ed. 1999, vol. 3.

Nedo, M., 1993. Einführung/Introduction to Ludwig Wittgenstein: Wiener Ausgabe/Vienna Edition. Vienna: Springer-Verlag. Excerpts reprinted in Flowers, ed. 1999, vol. 1.

Nedo, M., and M. Ranchetti, eds. 1983. Ludwig Wittgenstein: Sein Leben in Bildern und Texten. Frankfurt am Main: Suhrkamp.

Nelson, J., 1966. Letter to Sister Mary Elwyn McHale. August 13, 1966. Cornell University Library Special Collections.

Pascal, F., 1984. "Wittgenstein: A Personal Memoir". In Recollections of Wittgenstein, ed. R. Rhees. New York: Oxford University Press. Reprinted in Flowers, ed. 1999, vol. 2.

Paul, D., 2007. Wittgenstein's Progress: 1929-1951. Bergen: The Wittgenstein Archives at the University of Bergen.

Pinch, T, and R. Swedberg, 2016. "Wittgenstein at Cornell". In Flowers and Ground, eds. 2016, vol 2.

Pitt, J., 1981-1982. "Russell and the Cambridge Moral Sciences Club". Russell, n.s., 1, no. 2 (Winter): pp. 103-118.

Popper, K., 1974. "Autobiography”. In The Philosophy of Karl Popper. Vol. 1, ed. P. A. Schilpp. LaSalle, Ill.: Open Court. Excerpt reprinted in Flowers, ed. 1999, vol. 3.

Ramsey, F., 1991. “49. The Infinite”. In Notes on Philosophy, Probability and Mathematics, ed. M. Galvotti. Naples: Bibliopolis.

Rand, R., 2004. 'Wittgensteins Vorlesungen (1940/1941)". In Rand und Wittgenstein: Versuch und Annäherung. Wittgenstein-Studien, Band 9.

Redpath, T., 1990. Ludwig Wittgenstein: A Student's Memoir. London: Duckworth. Excerpts reprinted in Flowers, ed. 1999, vol. 3.

Rhees, R., 1939. Notes of Lectures by Wittgenstein, 1939. 3 vols. Wren Library, Trinity College, Cambridge.

Rhees, R., 1966. Letter to Sister Mary Elwyn McHale. On deposit at Cornell University Library Special Collections. December 2, 1966.

Rhees, R., 1984a. "Introductory Note". Philosophical Investigations 7, no. 1 (January), 1-2.

Rhees, R., 1984b. Postscript and editorial notes. In Recollections of Wittgenstein, ed. R. Rhees. New York: Oxford University Press. Reprinted in Flowers, ed. 1999, vol. 3.

Rhees, R., 1993. "The Language of Private Experience and Sense Data". In Philosophical Occasions: 1912-1951. Ed. J. C. Klagge and A. Nordmann. Indianapolis: Hackett. 
Rhees, R., 2015. “Wittgenstein's Philosophical Conversations with Rush Rhees (1939-1950): From the Notes of Rush Rhees”. Ed. G. Citron. In Mind, vol. 124, no. 493, 1-71.

Richards, I. A., 1972. “The Strayed Poet”. In Internal Colloquies, 183-186. London: Routledge. Excerpted in Monk 1990: 290.

Skinner, F., forthcoming. Ludwig Wittgenstein, Dictating Philosophy to Francis Skinner, The Wittgenstein-Skinner Manuscripts, ed. A. Gibson and N. O’Mahony. New York: Springer.

Sloan, P., ed. 1938. John Cornford: A Memoir. London: Jonathan Cape.

Smith, J., 2013. "Wittgenstein's Blue Book: Reading Between the Lines". In The Textual Genesis of Wittgenstein's Philosophical Investigations, ed. N. Venturinha. New York: Routledge.

Smythies, Y., 1993. "Lectures on Freedom of the Will". In Wittgenstein 1993.

Smythies, Y., n.d. Assorted notes and papers. Kagoshima International University, Japan. Microfilm at Wren Library, Trinity College, Cambridge.

Smythies, Y., 2017. Wittgenstein's Whewell's Court Lectures: Cambridge, 19381941: From the Notes by Yorick Smythies, eds. V. A. Munz and B. Ritter. Oxford: Wiley Blackwell.

Stern, J. P., 1989. Vorwort [Foreword] to Wittgenstein: Eine Ausstellung der Wiener Secession. Vol. 1, Biographie Philosophie Praxis. Vienna: Vienna Secession Exhibit, 11-31.

Stern, J. P., 1995. The Dear Purchase. New York: Cambridge University Press.

Toulmin, S., 1953. The Philosophy of Science: An Introduction. London: Hutchinson.

Townsend, R. D., 1930-1931. Notes of lectures by Wittgenstein, Michaelmas 1930 and Lent 1931. Wren Library, Trinity College, Cambridge.

Tranøy, K., 1976. "Wittgenstein in Cambridge: 1949-1951”. In Essays on Wittgenstein in Honour of G.H. von Wright. Acta Philosophica Fenica 28, no. 1-3, 11-21. Reprinted in Flowers, ed. 1999, vol. 4.

Trinity Mathematical Society minutes. Wren Library, Trinity College, Cambridge.

Venturinha, N., 2010. "The Ramsey Notes on Time and Mathematics". Trans. J.M. Thompson. In Wittgenstein after His Nachlass, ed. N. Venturinha. New York: Palgrave Macmillan.

Von Wright, G. H., ed. 1990. A Portrait of Wittgenstein as a Young Man: From the Diary of David Hume Pinsent, 1912-1914. Oxford: Basil Blackwell. Excerpts reprinted in Flowers, ed. 1999, vol. 1.

Wainwright, J. L., 2012. The Last to Fall: The Life and Letters of Ivor Hickmanan International Brigader in Spain. Southampton: Hatchet Green Publishing. 
Waismann, F., 1979. Wittgenstein and the Vienna Circle. New York: Barnes \& Noble.

Waismann, F., 1982. "Über das Wesen der Mathematik: Der Standpunkt

Wittgensteins". In Lectures on the Philosophy of Mathematics, ed. W. Grassl.

Amsterdam: Rodopi.

Waismann, F., 1986. “The Nature of Mathematics: Wittgenstein's

Standpoint". In Ludwig Wittgenstein: Critical Assessments. Vol. 3, From the

"Tractatus" to "Remarks on the Foundations of Mathematics", ed. S. Shanker.

London: Croon Helm.

Warnock, M., 2016. “A Tremendous Coup”. In Flowers and Ground, eds. 2016, vol. 2. London: Bloomsbury Press.

Watson, W.H., 1938. On Understanding Physics. Cambridge: Cambridge University Press.

Wisdom, J., 1952. 'Ludwig Wittgenstein, 1934-1937”. Mind 61, 258-260.

Reprinted in Flowers, ed. 1999, vol. 2.

Wittgenstein, L., 1958. The Blue Book and Brown Books, Oxford: Basil

Blackwell.

Wittgenstein, L., 1980/1998. Culture and Value, rev. $2^{\text {nd }}$ ed. Oxford: Basil Blackwell.

Wittgenstein, L., 1993. Philosophical Occasions: 1912-1951, eds. J. Klagge and A. Nordmann. Indianapolis: Hackett.

Wittgenstein, L., 1993a. "Cause and Effect: Intuitive Awareness".

Appendices A, B, C (including lecture notes by Rhees). In

Wittgenstein 1993.

Wittgenstein, L., 1993b. “A Lecture on Ethics”. In Wittgenstein 1993.

Wittgenstein, L., 1993c. Letter to the Editor of Mind. In Wittgenstein 1993.

Wittgenstein, L., 1993d. "Letters from Ludwig Wittgenstein to Georg Henrik von Wright". In Wittgenstein 1993.

Wittgenstein, L., 1993e. 'Notes for Lectures on 'Private Experience' and

'Sense Data"'. In Wittgenstein 1993.

Wittgenstein, L., 1993f. "Notes for the 'Philosophical Lecture"”. In

Wittgenstein 1993.

Wittgenstein, L., 1993g. "Some Letters from Wittgenstein”. In Wittgenstein 1993.

Wittgenstein, L., 1993-1996. Wiener Ausgabe/Vienna Edition. Vols. 1-5, ed. M. Nedo. Vienna: Springer-Verlag.

Wittgenstein, L., 1995. Cambridge Letters, eds. B. McGuinness and G. H. von Wright. Oxford: Basil Blackwell.

Wittgenstein, L., 1998. Leçons sur la Liberté de la Volunté, ed. A. Soulez and B.

McGuinness. Paris: Presses Universitaires de France.

Wittgenstein, L., 2000. Wiener Ausgabe/Vienna Edition. Vol. 8.1, ed. M. Nedo. Vienna: Springer-Verlag. 
Wittgenstein, L., 2003. Public and Private Occasions, eds. J. Klagge and A.

Nordmann. Lanham, Md: Rowman \& Littlefield.

Wittgenstein, L., 2003a. "Ludwig Hänsel—Ludwig Wittgenstein: A

Friendship". In Wittgenstein 2003.

Wittgenstein, L., 2003b. "Movements of Thought: Diaries, 1930-1932,

1936-1937”. In Wittgenstein 2003.

Wittgenstein, L., 2008. Wittgenstein in Cambridge: Letters and Documents, $1911-$ 1951, ed. B. McGuinness, Oxford: Blackwell.

Wittgenstein, L., 2014. Lecture on Ethics, eds. E. Zamuner, E. Di Lascio and

D. Levy. Oxford: Wiley Blackwell.

Wittgenstein, L., 2015-. Wittgenstein Source Bergen Nachlass Edition, ed.

Wittgenstein Archives at the University of Bergen under the

direction of A. Pichler. In: Wittgenstein Source [wittgensteinsource.org].

Bergen: WAB.

Wittgenstein, L., 2016-. Interactive Dynamic Presentation (IDP) of L.

Wittgenstein's philosophical Nachlass [http://wittgensteinonline.no/],

ed. Wittgenstein Archives at the University of Bergen under the

direction of A. Pichler. Bergen: WAB.

Wittgenstein, L., 2016a. Wittgenstein: Lectures, Cambridge 1930-1933: From the

Notes of G.E. Moore, eds. D. Stern, B. Rogers and G. Citron. New York:

Cambridge University Press.

Wittgenstein, L., 2019. Wittgenstein's Family Letters: Corresponding with Ludwig,

ed. B. McGuinness, trans. P. Winslow. London: Bloomsbury.

Young, Laurence C. 1981. Mathematicians and Their Times: History of Mathematics and Mathematics of History. Amsterdam: North Holland Publishing Co.

\section{Biographical note}

James C. Klagge is Professor of Philosophy at Virginia Tech, where he has taught since 1985. His first publication on Wittgenstein was in 1989, and he has since co-edited two collections of original material by Wittgenstein with Alfred Nordmann, Philosophical Occasions: 1912-1951 (Hackett, 1993) and Public and Private Occasions (Rowman \& Littlefield, 2003); edited a collection of essays Wittgenstein: Biography and Philosophy (Cambridge, 2001); and published two books, Wittgenstein in Exile (MIT, 2011) and Simply Wittgenstein (Simply Charly, 2016). Klagge is currently at work on two books, Wittgenstein's Artillery: Philosophy as Poetry and Tractatus in Context: Essential Background for Appreciating Wittgenstein's Tractatus Logico-Philosophicus (Routledge, forthcoming 2022). 